\title{
Recirculation of biomass ashes onto forest soils: Ash composition, mineralogy and leaching properties
}

\author{
Maresca, Alberto; Hyks, J.; Astrup, Thomas Fruergaard
}

Published in:

Waste Management

Link to article, DOI:

10.1016/j.wasman.2017.09.008

Publication date:

2017

Document Version

Peer reviewed version

Link back to DTU Orbit

Citation (APA):

Maresca, A., Hyks, J., \& Astrup, T. F. (2017). Recirculation of biomass ashes onto forest soils: Ash composition, mineralogy and leaching properties. Waste Management, 70, 127-138.

https://doi.org/10.1016/j.wasman.2017.09.008

\section{General rights}

Copyright and moral rights for the publications made accessible in the public portal are retained by the authors and/or other copyright owners and it is a condition of accessing publications that users recognise and abide by the legal requirements associated with these rights.

- Users may download and print one copy of any publication from the public portal for the purpose of private study or research.

- You may not further distribute the material or use it for any profit-making activity or commercial gain

- You may freely distribute the URL identifying the publication in the public portal

If you believe that this document breaches copyright please contact us providing details, and we will remove access to the work immediately and investigate your claim. 


\title{
Recirculation of biomass ashes onto forest soils: ash
}

\section{composition, mineralogy and leaching properties}

\author{
Maresca, A. ${ }^{*}$, Hyks, J. ${ }^{b} \&$ Astrup, T. F. ${ }^{a}$
}

a) Technical University of Denmark, Department of Environmental Engineering, Building 113, Miljoevej, 2800 Kgs. Lyngby, Denmark

b) Danish Waste Solutions ApS, Agern Allé 3, 2970 Hørsholm, Denmark

(1)

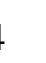




\section{Abstract}

In Denmark, increasing amounts of wood ashes are generated from biomass combustion for energy production. The utilisation of ashes on top of forest soil for liming purposes has been proposed as an alternative to landfilling. Danish wood ash samples were collected and characterised with respect to chemical composition, mineralogy and leaching properties (batch leaching at $\mathrm{L} / \mathrm{S} 2$ and $10 \mathrm{~L} / \mathrm{kg}$, and $\mathrm{pH}-\mathrm{dependent} \mathrm{leaching} \mathrm{at} 10$ $\mathrm{L} / \mathrm{kg}$ ). Large variations in the ash liming properties were observed ( $\mathrm{ANC}_{7.5}: 1.8-6.4 \mathrm{meq} \mathrm{H}^{+} / \mathrm{g}$ ), indicating that similar soil application dosages may result in different liming effects. High contents of $\mathrm{Ca}, \mathrm{Si}, \mathrm{P}, \mathrm{K}$ and $\mathrm{Mg}$ were observed in all samples, while the highest contents of $\mathrm{S}$ and $\mathrm{N}$ were found in fly ashes and mixed ashes (combination of fly and bottom ashes). Similarly, the highest contents of some trace metals, e.g. Cd, Mo and Se, were observed for fly ash. Releases of major, minor and trace elements were affected significantly by pH: high releases of $\mathrm{PO}_{4}{ }^{3-}, \mathrm{Mg}, \mathrm{Zn}, \mathrm{Cu}$ and $\mathrm{Cd}$ were found for acidic conditions relevant to forest soils, while the highest releases of Mo and $\mathrm{Cr}$ were observed in alkaline conditions. Mineral phases were selected based on XRD analyses and the existing literature, and they were applied as inputs for the geochemical modelling of $\mathrm{pH}-$ dependent leaching. Mineral dissolution was found adequate for a wide range of major elements and nutrients, while the description of trace elements could be done only for parts of the $\mathrm{pH}$-range. Content and leaching of PAHs were observed below detection limits. The source-term release of $\mathrm{Ca}, \mathrm{K}, \mathrm{Mg}, \mathrm{Mn}$, and $\mathrm{P}$ in acidic conditions relevant to forest soils was higher than ten years of atmospheric deposition, in contrast to the relatively low release of $\mathrm{Al}, \mathrm{Fe}$ and $\mathrm{Na}$. The potential release of $\mathrm{Cd}$ was found to be the most critical element compared with soil quality criteria, whereas the maximum theoretical loads of $\mathrm{Ba}, \mathrm{Cd}, \mathrm{Cr}, \mathrm{Sr}, \mathrm{Mo}, \mathrm{Ni}, \mathrm{Pb}, \mathrm{Sb}, \mathrm{Se}$, Sn and V were relatively low.

\section{Abbreviations}

ANC: acid neutralisation capacity; BA: bottom ash; CSH: calcium-silicate hydrates; DOC: dissolved organic carbon; dw: dry weight; FA: fly ash; ICP: inductively coupled plasma; LOD: limit of detection; MA: mixed ash; MSWI: municipal solid waste incineration; OCP: octacalcium phosphate; PAH: polycyclic aromatic hydrocarbon; SI: saturation index; SQC: soil quality criteria; TOC: total organic carbon; XRD: X-ray diffraction 
Many European countries are introducing increasing amounts of renewable energy sources at the expense of fossil fuels (European Commission, 2015). In addition to wind and photovoltaic options, biomass often plays an important role in this transition. The Danish district heating system is based on many distributed combined heatand-power plants supplying both electricity and district heating for the surrounding local region. Many of these plants utilise wood chips as fuel for combustion, and many of the larger coal power plants are currently being converted into wood pellet combustors, at the expense of coal. This follows the current Danish energy strategy of being fossil fuel independent by 2050 (The Danish Council on Climate Change, 2015). The production of electricity from wood has shown a significant increase within the last decade, i.e. from $0.8 \mathrm{PJ}$ to 8 PJ in the period 2000 - 2015 (Danish Energy Agency, 2016). The increased use of woody biomass fuels, however, results in the increased production of wood ashes; in Denmark, about 22,300 tonnes dry weight (dw) of wood ash was produced in 2012 (Skov and Ingerslev, 2013).

The use of wood ashes on forest and agricultural soil is regulated in some European countries, such as Denmark, Finland, Sweden, Austria and Germany (van Eijk et al., 2012). In Denmark, for example, the dosage of ash applied to forest soil (DEPA, 2008) is regulated depending on (i) the content of specific contaminants in the ash, (ii) the need for plant fertiliser and (iii) the ash's electrical conductivity: a maximum of three tonnes/ha can be applied over a period of 10 years, but not more than three times within the last 75 years. There are approximately 615,000 hectares of forest land in Denmark, which in principle could receive wood ashes. Nevertheless, most of the wood ashes currently produced in Denmark are collected in containers at individual plants and landfilled (Ingerslev et al., 2014), most likely because of the small capacity of the Danish power plants (and therefore relatively small quantities of ashes), stringent legislation limits, concerns about their composition and leachability and the costs associated with the chemical analysis and documentation of ash quality. However, with increasing amounts of wood ashes being generated, landfilling is not a viable solution from a long-term perspective, in that the sustainability of wood combustion requires the continuous renewal of forest biomass and the input of nutrients. The application of wood ashes in forestry may contribute to the recirculation of nutrients (e.g. K, $\mathrm{Mg}, \mathrm{Ca}$ and P) as well as offer liming effects on the soil (Pitman, 2006) - using three tonnes of wood ashes on top of soil was reported to have a liming effect comparable to one tonne of $\mathrm{CaO}$ (Karltun et al., 2008). On the other hand, recirculating wood ashes onto forest soil may also result in undesired releases of contaminants. Specific focus, for example, has been placed on $\mathrm{Cd}$, which has been investigated for its potential bioavailability and toxicity in relation to specific soil ecosystems (e.g. Cruz-Paredes et al., 2017; Fritze 
et al., 2001; Perkiömäki and Fritze, 2005). Hence, although the potential for increasing the recirculation of wood ashes to forestry may exist in Denmark, further clarification on the consequences of this process is needed. According to the available literature, the composition of wood ash has been addressed as a function of biomass fuel (Drift et al., 2001; Reimann et al., 2008; Werkelin et al., 2011), furnace operating parameters (Etiégni and Campbell, 1991; Misra et al., 1993; Sarenbo, 2009), combustion technology (Freire et al., 2015; Lanzerstorfer, 2015; Pöykiö et al., 2007) and different ash types (Dahl et al., 2009; Ingerslev et al., 2011; Sano et al., 2013). Several authors have investigated the leaching of wood ash, by applying different methods such as sequential extractions, batch leaching tests and percolation tests (Liodakis et al., 2009; Mellbo et al., 2008; Pöykiö et al., 2012; Sano et al., 2013; Steenari et al., 1998, 1999; Supancic et al., 2014). However, due to the different leaching test conditions applied in these studies, a direct comparison of results taken from individual studies is not possible. Despite a recent study by Freire et al. (2015), who characterised the leaching of a few wood ash samples under different leaching conditions, existing literature is relatively fragmented, Moreover, a systematic evaluation of the variability of leaching from a wider range of ashes, and an evaluation of the leaching mechanisms controlling the release of nutrients and contaminants from these ashes, is largely missing. A consistent evaluation of the leaching properties of these ashes is needed as the basis for future changes in the regulatory framework targeting the minimisation of the landfilling of wood ashes.

The overall aim of this study is to provide a consistent evaluation of the leaching properties of wood ashes, in order to improve the knowledge necessary for recirculating these combustion residues onto forest soils. This includes the following specific objectives: (i) to document variability in ash composition and leaching behaviour over a range of wood ash samples, (ii) to evaluate the effects of $\mathrm{pH}$ in relation to leaching for selected ashes, (iii) to identify and interpret key mechanisms controlling leaching by means of geochemical modelling and (iv) to evaluate potential source-term releases onto forest soils with respect to soil quality criteria and atmospheric deposition.

\section{MATERIALS AND METHODS}

\subsection{Sampling and material handling}

Ashes from ten different Danish biomass combustion facilities (see Table S1 in Supplementary Material for more details on the characteristics of these plants) receiving wood chips, mainly from Picea Abies, were sampled in the period January - March 2014. Depending on the specific technology, freshly generated bottom ash (BA) and 
fly ash (FA) may be collected at the plant through two separate flows or one single mixed flow (fresh mixed ash:

110 MA). The latter was a specific case of closed ash conveyer systems, where it was not possible to sample BA and

111 FA separately. Consequently, the ratio between BA and FA in the MA samples was not known. A total of sixteen

112 wood ash samples were collected: three BA, four FA and nine MA samples. Sample names used in the following

113 text refer to the ash type, i.e. $B A, F A$ or $M A$, followed by a number representing the plant, i.e. 1-10, and an

114 optional letter, i.e. $a, b$ or $c$, indicating the replicate number (where relevant). Upon receipt of the samples at the

115 laboratory, the mass of each sample was reduced by quartering and splitting, using a riffle splitter in accordance

116 with ASTM C702/C702M: 2011. All samples were stored in airtight plastic containers at $10^{\circ} \mathrm{C}$ prior to testing

117 and characterisation.

\subsection{Ash characterisation}

Moisture content was determined on $100 \mathrm{~g}$ subsamples according to EN 1097-5: 2008. Next, the dry material was crushed in a jaw crusher and then pulverised in a vibratory disc mill (agate discs). Approximately $0.2 \mathrm{~g}$ subsamples of the powder were obtained by consecutive riffle splitting and used for determining total organic carbon (TOC; EN 13137: 2001; LECO induction furnace CS-200 Analyser) and contents of C, S, N and H (Elemental Analyser - Vario MACRO cube); triplicate analyses were carried out. The elemental composition of the wood ash samples was determined in duplicates using $0.25 \mathrm{~g}$ of pulverised material for microwave-assisted acid digestion (Multiwave Anton Paar 3000) according to EN 13656: 2003, using $6 \mathrm{ml}$ of $\mathrm{HNO}_{3}(65 \%), 2 \mathrm{ml}$ of $\mathrm{HCl}(37 \%), 2 \mathrm{ml}$ of $\mathrm{HF}(40 \%)$ and $12 \mathrm{H}_{3} \mathrm{BO}_{3}(10 \%)$. In addition, $2 \mathrm{ml}$ of $\mathrm{H}_{2} \mathrm{O}_{2}(30 \%)$ was added to enhance the oxidation of residual organic matter. The digestates were analysed by inductively coupled plasma (ICP) mass spectrometry (7700x, Agilent Technologies) for the content of $\mathrm{Al}, \mathrm{Ag}, \mathrm{As}, \mathrm{Au}, \mathrm{Ba}, \mathrm{Be}, \mathrm{Ca}, \mathrm{Cd}, \mathrm{Ce}, \mathrm{Co}, \mathrm{Cr}, \mathrm{Cs}$, $\mathrm{Cu}, \mathrm{Er}, \mathrm{Eu}, \mathrm{Fe}, \mathrm{Ga}, \mathrm{Gd}, \mathrm{Ge}, \mathrm{Hf}, \mathrm{Ho}, \mathrm{In}, \mathrm{Ir}, \mathrm{K}, \mathrm{La}, \mathrm{Li}, \mathrm{Lu}, \mathrm{Mg}, \mathrm{Mn}, \mathrm{Mo}, \mathrm{Na}, \mathrm{Nb}, \mathrm{Nd}, \mathrm{Ni}, \mathrm{P}, \mathrm{Pb}, \mathrm{Pd}, \mathrm{Pr}, \mathrm{Pt}, \mathrm{Rb}, \mathrm{Re}$, Rh, Ru, Sb, Sc, Se, Si, Sm, Sn, Sr, Ta, Tb, Ti, Tl, Tm, V, W, Yb, Zr and Zn, and by ICP optical emission spectrometry (Varian Vista-MPX) for the content of $\mathrm{Ca}, \mathrm{K}, \mathrm{Mn}$ and $\mathrm{S}$. The same procedure was repeated to a reference material, i.e. $B C R-176 R$, to validate the results. ash samples were selected with the following characteristics: a) one ash sample with the highest $\mathrm{Cd}$ content among the sixteen samples (FA-2b, consisting of fly ash) and b) one ash sample complying with the current 
of both fly ash and bottom ash). As such, the two selected samples represented a "worst case scenario" with regards to the content of $\mathrm{Cd}$, and a "typical situation" with ashes that are today allowed for recirculation in

140 forestry settings. Further characterisation of the two selected samples, i.e. MA-9c and FA-2b, included: (i)

141 determining particle size distribution, (ii) XRD scanning, (iii) analysis of the content of polycyclic aromatic

142 hydrocarbons (PAHs; US EPA, 2008), using GC-MS after Soxhlet extraction using dichloromethane (US EPA

143 8270D, 2014), (iv) and leaching characterisation based on a range of different leaching tests (Section 2.4 and

144 2.5). Particle size distribution was determined in triplicate according to EN 933-1:2012, using $250 \mathrm{~g}$ of

145 previously dried $\left(110^{\circ} \mathrm{C}\right)$ samples by means of 13 stainless steel sieves with mesh sizes ranging between 0.063

$146 \mu \mathrm{m}$ and $25 \mathrm{~mm}$. XRD scanning was carried out on pulverised samples of MA-9c and FA-2b, using a Philips PW

$1471830 \mathrm{X}$-ray diffractometer equipped with a copper tube operated at $40 \mathrm{kV}$ and $50 \mathrm{~mA}$. Diffraction patterns were

148 collected over a 2-theta range from $2^{\circ}$ to $65^{\circ}$, employing an angular step of $0.05^{\circ}$ and a count time of $2 \mathrm{~s}$.

\subsection{Batch leaching experiments}

151 All sixteen samples, except FA-1 and FA-3 (insufficient sample amounts), were subjected to a batch leaching 152 test (EN 12457-1:2002) at a liquid-to-solid (L/S) ratio of $2 \mathrm{~L} / \mathrm{kg}$. In addition, MA-9c and FA-2b underwent a 153 batch leaching test at L/S $10 \mathrm{~L} / \mathrm{kg}$ (EN 12457-2:2002). Electrical conductivity and $\mathrm{pH}$ were measured in 154 unfiltered eluates immediately after the leaching test. Eluates were then filtered $(0.45 \mu \mathrm{m}$,

155 Polytetrafluoroethylene) and divided into a number of subsamples for subsequent analysis. Subsamples intended 156 for ICP analysis were acidified by adding $\mathrm{HNO}_{3}$ (p.a.) to $\mathrm{pH}<2$, while subsamples for analysis of chlorides 157 (potentiometric titration with $\mathrm{AgNO}_{3}$,Tim 865 Titration Manager), dissolved organic carbon (DOC) and 158 dissolved total carbon (Shimadzu TOC 5000A Analyser) were not acidified. All eluate samples were kept at $4^{\circ} \mathrm{C}$ 159 prior to the analyses.

160

\section{$2.4 \mathrm{pH}-$ dependent batch leaching experiments}

162 The influence of $\mathrm{pH}$ on the leaching of MA-9c and FA-2b was tested according to CEN/TS 14997:2006(E), 163 using a computer-controlled titration system. Eight $\mathrm{pH}$ values were investigated: 2, 4, 5.5, 7, 8.5, 10, 11.5 and

164 natural $\mathrm{pH}$ (without the addition of acid). The acid neutralisation capacity (ANC) of both ash samples was tested 165 prior to the actual leaching test (see Section S1 in Supplementary Material for more details on the ANC test).

166 About $60 \mathrm{~g} \mathrm{dw}$ of ash was added with distilled water and continuously mixed, and then $\mathrm{HNO}_{3}$ was added to 
achieve and maintain the predefined $\mathrm{pH}$ values for 48 hours. At the end of the experiment, $\mathrm{pH}$, electrical conductivity and redox potential were measured in the eluate samples, which were then filtered $(0.45 \mu \mathrm{m}$, Polytetrafluoroethylene), acidified for the fraction undergoing ICP measurements, stored and finally analysed similarly to eluates from the batch leaching test.

\subsection{Equilibrium column experiments for organic compounds}

The release of organic compounds from MA-9c and FA-2b was evaluated using an equilibrium column test according to Nordtest TR576 (2004). In this test, the leachant (0.005 $\mathrm{M} \mathrm{CaCl}_{2}$ and $0.5 \mathrm{~g} \mathrm{NaN}_{3}$ ) was recirculated (flow rate: $20 \mathrm{ml} / \mathrm{h}$ ) by the sample being packed in a stainless steel column for 6 days (L/S ratio $6 \mathrm{~L} / \mathrm{kg}$ ). At the end of the test, $\mathrm{pH}$ and conductivity were measured in the eluates, and these were then analysed for sixteen PAH compounds, as defined by US EPA (2008), using a GC-MS after extraction with acetone/pentane (1:1), according to the Danish method Reflab 4:2008.

\subsection{Geochemical modelling of pH-dependent leaching}

The results of the $\mathrm{pH}$-dependent leaching experiments were used to describe the leaching behaviour of major components (K, $\mathrm{Ca}, \mathrm{Si}, \mathrm{Mg}, \mathrm{Mn}, \mathrm{Al}, \mathrm{Fe}, \mathrm{PO}_{4}{ }^{3-}$ and $\mathrm{SO}_{4}{ }^{2-}$ ) in both samples, using the so-called "geochemical multi-surface modelling approach" (Dijkstra et al., 2008). All model calculations were carried out using the ORCHESTRA modelling framework (Meeussen, 2003) embedded in a LeachXS database/expert system (http://www.leachxs.com/lxsdll.html). Thermodynamic data from the MINTEQA2 thermodynamic database, as modified by Butera et al. (2015), were used.

In the first modelling step, chemical speciation of the solutions obtained from the $\mathrm{pH}$-dependent batch leaching experiments was used to identify "plausible" (explained later) mineral solubility controlling phases assuming equilibrium conditions. In a subsequent modelling step, the total concentrations of available trace metal(-loid)s were included in the calculations. These metal(-loid)s were allowed to react with different reactive surfaces through sorption (explained later), while ion competition was enabled. Similarly to the approach taken by Dijkstra et al. (2006b), total available trace metal(-loid) concentrations were estimated from the maximum values obtained in the $\mathrm{pH}$-dependent leaching experiments. Except for Mo, which showed maximum solution concentrations at $\mathrm{pH} \sim 10$, all other trace metal(-loid)s (i.e. including oxyanion-forming metalloids such as $\mathrm{As}, \mathrm{Cr}$, $\mathrm{Sb}, \mathrm{Se}$ and $\mathrm{V}$ ) showed maximum solution concentrations at $\mathrm{pH} 2$. 

using generic adsorption reactions (Milne et al., 2003). Adsorption onto Fe-/Al-(hydr)oxides was calculated using the generalised two-layer model provided by Dzombak and Morel (Dzombak and Morel, 1990). The availability of sorption surfaces was represented by amounts of reactive Fe- and Al-(hydr)oxides, and the amounts of $\mathrm{Fe}$ - and $\mathrm{Al}$-(hydr)oxides were estimated based on $\mathrm{Fe}$ and $\mathrm{Al}$ solution concentrations measured in the eluates from the $\mathrm{pH}$-dependent leaching tests at $\mathrm{pH}$ 2, since the majority of $\mathrm{Fe}$ - and $\mathrm{Al}$ - (hydr)oxides dissolve at this pH (Gayer et al., 1958; Gayer and Woontner, 1956). While the amounts of available (hydr)oxides may also be estimated via selective extractions (e.g. Apul et al., 2010; Dijkstra et al., 2006a), both approaches represent indirect estimations associated with some uncertainty. Here, estimations based on eluate concentrations at low $\mathrm{pH}$ were considered appropriate, while it is acknowledged that compared to dedicated selective extractions, the approach used herein may possibly cause an overestimation of reactive site concentrations, which may in turn overestimate the significance of adsorption in the geochemical model. speciation calculations. Selection was based on a step-wise procedure. First, minerals with saturation indices (SI) within the interval \pm 0.5 were listed - SI around " 0 " indicate that a particular mineral is approaching equilibrium with the solution and may thus control (provided it is physically present) solution concentrations of its components. This initial list is theoretical and can be rather extensive depending on the number of minerals present in the mineralogy database used by the speciation model. Therefore, additional confirmation is needed to evaluate whether a certain mineral is actually present (or likely to be present) in the modelled system. Despite the challenges caused by a relatively large fraction of the material being non-crystalline, results from XRD analyses are useful in confirming the presence of many major mineral phases. from the literature (e.g. Freire et al., 2015; Magdziarz et al., 2016; Vassilev et al., 2013). Nevertheless, since more than 200 different mineral phases have been found in different types of "bioashes" (Vassilev et al., 2013), only minerals found in more than five independent studies were considered "plausible" in our model. For the fly ash (FA-2b), the final list of "plausible" mineral phases put into the geochemical model of the pH-dependent leaching included phases determined by our XRD analysis (calcite, portlandite, quartz, periclase, maghemite and calcium silicate) and phases identified from the literature (gibbsite, microcline, leucite, magadiite, CSH, brucite, birnessite, hydroxyapatite, octacalcium phosphate (OCP) and $\left.\mathrm{Ba}_{0.5} \mathrm{Sr}_{0.5} \mathrm{SO}_{4}\right)$. Analogically, for the mixed ash 
(MA-9c), the list included calcite, lime, portlandite, quartz, ankerite, magnesite (based on the XRD results) and calcium silicate, $\mathrm{CSH}$, OCP, microcline, maghemite, leucite, magadiite, brucite, birnessite, zincite and $\mathrm{Ba}_{0.5} \mathrm{Sr}_{0.5} \mathrm{SO}_{4}$ (based on the literature). Table $\mathrm{S} 2$ in Supplementary Material provides the full list of minerals identified during this study, along with the respective chemical formula. "plausible" solubility controlling minerals, (iii) reactive Fe-(hydr)oxide sites approximated by "ferrihydrite" (surface area of $600 \mathrm{~m}^{2} / \mathrm{g}$ and capacity of $1.37 \cdot 10^{-4} \mathrm{~kg} / \mathrm{kg}$ and $9.73 \cdot 10^{-5} \mathrm{~kg} / \mathrm{kg}$ for MA-9c and FA-2b, respectively) and (iv) a polynomial description of the DOC concentration as a function of $\mathrm{pH}$. Model II was identical to Model I, albeit with the addition of adsorption to Al-(hydr)oxides. Similarly to Fe-(hydr)oxides, the maximum content of reactive $\mathrm{Al}$-(hydr)oxides was estimated from the $\mathrm{pH}$-dependent leaching data for $\mathrm{Al}$ (at $\mathrm{pH}$ 2) and treated as a surrogate sorbent to the Fe-(hydr)oxides (Dijkstra et al., 2006a, 2006b). The combined contribution of $\mathrm{Fe}$ - and $\mathrm{Al}$-(hydr)oxides yielded $7.62 \cdot 10^{-3} \mathrm{~kg} / \mathrm{kg}$ and $7.83 \cdot 10^{-3} \mathrm{~kg} / \mathrm{kg}$ of "ferrihydrite" for MA-9c and FA-2b, respectively. Model II additionally included - based on literature screening and calculated SIs - a few additional mineral phases that might be relevant in the mineral assemblage: $\mathrm{Cu}(\mathrm{OH})_{2(\mathrm{~s})}, \mathrm{PbMoO}_{4}$, willemite, $\mathrm{ZnO}_{(\mathrm{s})}$ and $\mathrm{Cl}$-pyromorphite. In order to ensure ion competition, all calculations were carried out simultaneously for $\mathrm{Al}, \mathrm{Ba}, \mathrm{Ca}, \mathrm{Cd}, \mathrm{Cl}^{-}, \mathrm{CO}_{3}{ }^{2-}, \mathrm{Cr}, \mathrm{Cu}, \mathrm{Fe}, \mathrm{Si}, \mathrm{As}, \mathrm{K}, \mathrm{Li}, \mathrm{Mg}, \mathrm{Mn}, \mathrm{Mo}, \mathrm{Na}, \mathrm{Ni}, \mathrm{Pb} \mathrm{PO}_{4}{ }^{3-}, \mathrm{Sb}, \mathrm{Se}, \mathrm{Sr}, \mathrm{SO}_{4}{ }^{2-}, \mathrm{V}, \mathrm{Zn}$ and DOC. An oxidising environment was assumed during the calculations ( $\mathrm{pe}+\mathrm{pH}=15)$.

\subsection{Comparison with soil quality and atmospheric deposition}

To evaluate the potential source-term releases from wood ashes when applied to top of soil, a hypothetical scenario was considered, based on the two samples MA-9c and FA-2b. In this scenario, the two ashes were assumed to be placed on top of $1 \mathrm{~m}^{2}$ of an acidic Danish forest soil with a pH value in the range 3-5 (for typical pH values in Danish soil, refer to Balstrøm et al. (2013)), at the maximum allowed dosage of $300 \mathrm{~g} / \mathrm{m}^{2}$ (see Introduction). In forest applications, wood ashes are typically spread on top of the soil and not further worked with it. Due to the limited amount of ash added to the top of the soil, overall ash leaching could be expected to be dominated by the acidic properties of the soil, rather than the alkaline properties of the ashes. As such, the source-term release from the ashes was estimated based on $\mathrm{pH}$-dependent leaching $(\mathrm{pH} \mathrm{3-5,} \mathrm{L} / \mathrm{S} 10 \mathrm{~L} / \mathrm{kg}$ ), itself based on the defined ash dosage $\left(300 \mathrm{~g} / \mathrm{m}^{2}\right)$ and soil area $\left(1 \mathrm{~m}^{2}\right)$, and it was expressed in $\mathrm{mg} / \mathrm{m}^{2}$. In addition, the maximum theoretical load of nutrients and potential contaminants entering the soil was evaluated based on ash 
composition, assuming that all solid contents would be released into the soil at some point in time. Although this is unlikely to happen within a foreseeable time frame (see Astrup et al., 2006), the maximum theoretical loads can still be compared with soil quality criteria levels (described in the following paragraph) to indicate the level of relevance. Similarly to the ash source-term releases, maximum theoretical loads were expressed in $\mathrm{mg} / \mathrm{m}^{2}$. The potential soil-leachate interaction is beyond the scope of this investigation.

Ash contents and calculated releases were compared with data for Danish atmospheric deposition (Hovmand and Kystol, 2013) and soil quality criteria (SQC) for "very sensitive land use" (DEPA, 2015). In Denmark, wood ashes cannot be recirculated on top of forest soil sooner than ten years from the last application (DEPA, 2008); accordingly, ten years' worth of cumulative atmospheric depositions (based on average annual data) were chosen for comparison with wood ash levels. Atmospheric deposition data were expressed in $\mathrm{mg} /\left(\mathrm{m}^{2}\right.$ $\cdot 10 \mathrm{y})$. As there are no SQC for Co, Sr or V, the reported soil values for these elements referred to typical Danish farmland contents (DEPA, 1995), average mineral soil composition (Capo et al., 1998) and California Human Health Screening Levels in the case of a residential scenario (OEHHA, 2010), respectively.

SQC (expressed in $\mathrm{mg} / \mathrm{kg}$ ) were converted into threshold values (expressed per volume of soil, i.e. $\left.\mathrm{mg} /\left(\mathrm{m}^{2} \cdot \mathrm{cm}\right)\right)$, assuming a soil area of $1 \mathrm{~m}^{2}$, a soil depth of $1 \mathrm{~cm}$ and a soil bulk density of $1.1-1.5 \mathrm{~g} / \mathrm{cm}^{3}$. The rationale for choosing a soil depth of $1 \mathrm{~cm}$ was to allow direct comparison between the "layer" of ash $\left(300 \mathrm{~g} / \mathrm{m}^{2}\right)$ and the uppermost part of the soil.

\section{RESULTS AND DISCUSSION}

\subsection{Ash composition}

Table 1 shows the chemical composition of the sixteen ash samples grouped by ash type, i.e. BA, FA and MA, compared to values found in relevant literature. A detailed composition of MA-9c and FA-2b is presented in Supplementary Material (Table S3), together with particle size distribution curves (Figure S1) showing $90 \%$ and $70 \%$ of FA-2b and MA-9c as being smaller than $1 \mathrm{~mm}$ (similar curves were reported by Lanzerstorfer (2015) and Supancic et al. (2014) for grate-fired wood ashes).

\section{<Table 1>}

The chemical composition of the sixteen samples was comparable to literature values for all major, minor and trace elements. The most abundant elements were $\mathrm{Ca}$ and $\mathrm{Si}$ with contents of about $10^{5} \mathrm{mg} / \mathrm{kg} \mathrm{dw}$. With regards to typical plant nutrients, high contents of $\mathrm{P}, \mathrm{K}$ and $\mathrm{Mg}$ were found (about $10^{4} \mathrm{mg} / \mathrm{kg} \mathrm{dw}$ ), whereas 
the content of $\mathrm{N}$ was observed to be related strongly to the ash type (i.e. $<400 \mathrm{mg} / \mathrm{kg} \mathrm{dw}$ and up to $4900 \mathrm{mg} / \mathrm{kg}$ $\mathrm{dw}$ in the case of BA and FA, respectively), most likely because of the low volatising point of $\mathrm{N}$ in the combustion chamber. S content varied by up to two orders of magnitude $\left(10^{2}-10^{4} \mathrm{mg} / \mathrm{kg}\right)$, with the highest values found in FA samples. The same partitioning tendency was observed for $\mathrm{Cu}$ and $\mathrm{Zn}\left(10^{1}-10^{2} \mathrm{mg} / \mathrm{kg}\right.$ and $10^{1}-10^{3} \mathrm{mg} / \mathrm{kg}$, respectively). Several trace metal(-loid)s seemed occasionally to be enriched in FA samples compared with BA samples, i.e. $\mathrm{Cd}$, Mo, $\mathrm{Se}, \mathrm{Sn}, \mathrm{Sr}$ and Tl; however, the content of trace metal(-loid)s in the samples showed to be generally independent of the actual ash type, e.g. As, $\mathrm{Ba}, \mathrm{Co}, \mathrm{Cr}, \mathrm{Ni}, \mathrm{Pb}, \mathrm{Sb}$ and $\mathrm{V}$. These findings were consistent with other wood ash studies (e.g. Freire et al., 2015; Ingerslev et al., 2011; Pöykiö et al., 2012).

The overall levels of "critical elements", as defined by the European Commission (2014), and other trace elements were comparable to Vassilev et al. (2014), except for $\mathrm{Ce}, \mathrm{La}, \mathrm{Nd}$ and $\mathrm{Nb}$, but typically lower than municipal solid waste incineration (MSWI) BA and considerably lower than typical ore concentrations (see Allegrini et al. (2014) and the literature cited herein). Detailed information about these elements is provided in Table S4 in Supplementary Material and will not be discussed further.

TOC levels in the sixteen samples were generally between $0.28 \%$ and $33 \%$ (except for a few high values for FA-1, FA-3 and MA-7), which was comparable with the 0.8 \%-13\% reported by Bjurström et al. (2014).

\subsection{X-Ray Diffraction (XRD)}

The XRD analysis of MA-9c indicated calcite, lime, portlandite, quartz, ankerite and magnesite, while FA-2b contained calcite, portlandite, quartz, periclase, maghemite and calcium silicate (Figure 1). These results are in agreement with a recent review of "bioash" mineralogy data by Vassilev et al. (2013).

\section{<Figure 1>}

\subsection{Batch leaching results}

Results of the batch leaching tests are presented in Table 2 together with literature data for wood ashes. Overall, the release of major components, nutrients and typical elements of environmental concern reflected levels found in the literature. Detailed results for "critical elements" and other trace elements can be found in Supplementary Material (Table S5) and will not be discussed further. 
All leachates were strongly alkaline, with $\mathrm{pH}$ ranging between 11.9 and 13.8 (mean value of 13.2).

314 Electrical conductivity was measured between 9.2 and $69 \mathrm{mS} / \mathrm{cm}$, showing a positive correlation with $\mathrm{K}$ concentrations: high (/low) K leachate concentrations reflected in high (/low) electrical conductivity values, and vice versa. The release of DOC was between $10^{-3}$ and $10^{-1} \mathrm{mg} / \mathrm{kg}$ dw at $\mathrm{L} / \mathrm{S} 2 \mathrm{~L} / \mathrm{kg}$, while dissolved total carbon levels were between $10^{-2}$ and $10^{0} \mathrm{mg} / \mathrm{kg} \mathrm{dw}$.

The release of $\mathrm{Cl}, \mathrm{K}, \mathrm{Na}$, and $\mathrm{S}$ appeared to be dominated by the rapid dissolution of readily soluble phases. Significant amounts of these elements were released in the batch leaching test at L/S $2 \mathrm{~L} / \mathrm{kg}$ by all ash samples: $\mathrm{Cl}, \mathrm{Na}$ and $\mathrm{S}$ were released in the range of $10^{2}-10^{3} \mathrm{mg} / \mathrm{kg} \mathrm{dw}$, while the release of $\mathrm{K}$ was between $10^{3}$ and $10^{4} \mathrm{mg} / \mathrm{kg} \mathrm{dw}$. Furthermore, comparable releases at $\mathrm{L} / \mathrm{S} 2 \mathrm{~L} / \mathrm{kg}$ and at $10 \mathrm{~L} / \mathrm{kg}$ were observed for each of the two samples subjected to both types of batch leaching test (i.e. MA-9c and FA-2b). This kind of leaching behaviour reflects a mechanism also known as "availability controlled leaching" (Kosson et al., 1996), which is typical for readily soluble phases. Overall, the release of $\mathrm{Cl}, \mathrm{K}, \mathrm{Na}$ and $\mathrm{S}$ reflected typical literature ranges, whereas the release of Na from BA samples (i.e. $280-1000 \mathrm{mg} / \mathrm{kg}$ at $\mathrm{L} / \mathrm{S} 2 \mathrm{~L} / \mathrm{kg}$ ) was about five to six times higher than literature data (i.e. $42-200 \mathrm{mg} / \mathrm{kg}$ at $\mathrm{L} / \mathrm{S} 10 \mathrm{~L} / \mathrm{kg}$ ). the $\mathrm{L} / \mathrm{S} 10 \mathrm{~L} / \mathrm{kg}$ batch test, was higher than from the $\mathrm{L} / \mathrm{S} 2 \mathrm{~L} / \mathrm{kg}$ test, thereby suggesting that their release was controlled by mineral solubility, similar to that observed in in MSWI BA (Dijkstra et al., 2006a; Hyks et al., 2009). $\mathrm{Cu}, \mathrm{Fe}, \mathrm{Mg}, \mathrm{Mn}, \mathrm{P}$ and $\mathrm{Zn}$ were released at very low levels and generally below $1 \mathrm{mg} / \mathrm{kg}$ at $\mathrm{L} / \mathrm{S} 2 \mathrm{~L} / \mathrm{kg}$. Solution concentrations of $\mathrm{Cd}, \mathrm{Co}, \mathrm{Sb}, \mathrm{Sn}$ and $\mathrm{Tl}$ were typically found below their respective limit of detection (LOD), regardless of ash type. The release of Mo was in the order of $10^{-1}-10^{0} \mathrm{mg} / \mathrm{kg} \mathrm{dw}$, and similar releases were shown at both $\mathrm{L} / \mathrm{S} 2 \mathrm{~L} / \mathrm{kg}$ and $10 \mathrm{~L} / \mathrm{kg}$, thus suggesting the leaching of this element to be availability controlled. The release of $\mathrm{Cr}, \mathrm{Ni}$, and $\mathrm{V}$ varied significantly, i.e. $10^{-3}-10^{0} \mathrm{mg} / \mathrm{kg} \mathrm{dw}$ (L/S $2 \mathrm{~L} / \mathrm{kg}$ ), across all sample types, while a narrower release range was observed for $\mathrm{Pb}$, Se and $\mathrm{Sr}$. Similar releases have been established in wood ash literature (see Table 2).

\subsection{Content and leaching of PAHs}


342 2012), where high values have been explained by insufficient oxidation during the combustion process (Sarenbo,

343 2009; Straka and Havelcová, 2012; Vehlow and Dalager, 2011). The observed PAH levels in the ashes tested

344 herein were about two orders of magnitude below Danish limit values for the utilisation of wood ash on the top

345 of soil, i.e. $12 \mathrm{mg} / \mathrm{kg}$ (DEPA, 2008), and about one order of magnitude below Danish SQC defined for soils

346 intended for "very sensitive land use", i.e. $4 \mathrm{mg} / \mathrm{kg}$ (DEPA, 2015).

The leaching of naphthalene, acenaphthylene, acenaphthene, fluorene, phenanthrene, anthracene,

348 fluoranthene, pyrene, benzo[a]pyrene, dibenz[a,h]anthracene, benzo[ghi]perylene and indeno[1,2,3-cd]pyrene

349 was below LOD $(0.01 \mu \mathrm{g} / \mathrm{l})$ in eluates from both FA-2b and MA-9c subjected to an equilibrium column test.

350 Similarly, the leaching of benz[a]anthracene/chrysene and benzo[bjk]fluoranthene was below LOD $(0.02 \mu \mathrm{g} / \mathrm{l})$.

351 The low PAH levels observed in the experiments did not provide a basis to investigate potential interactions

352 between the leaching of organic and inorganic compounds. Likewise, Enell et al. (2008) reported low PAH

353 leachability from wood fly ash pellets, despite their considerably higher PAHs content (1.8 g/kg dw), as only

354 about $0.02 \%$ of the initial PAHs content was released at L/S $1600 \mathrm{~L} / \mathrm{kg}$. As such, while biomass ashes have been

355 shown to contain organic pollutants as a consequence of incomplete combustion, the two ashes selected here

356 indicated low levels. While this may not exclude high contents in ashes from other plants, results from these two

357 samples, in combination with the literature, may suggest that the release of PAHs is not a primary concern with

358 respect to the recirculation of wood ashes onto forest soil.

\subsection{Results of the pH-dependent leaching test}

\subsubsection{Acid neutralising capacity}

362 In spite of similar natural $\mathrm{pH}$ values, i.e. $~ 12.7$ at $\mathrm{L} / \mathrm{S} 10 \mathrm{~L} / \mathrm{kg}$, the $\mathrm{ANC}$ of the two materials differed

363 significantly (Figure $\mathrm{S} 2$ in Supplementary Material): $\mathrm{ANC}$ at the end-point of $\mathrm{pH} 2\left(\mathrm{ANC}_{2}\right)$ was $6.5 \mathrm{meq} \mathrm{H}^{+} / \mathrm{g}$

$364 \mathrm{dw}$ and 15.5 meq H $\mathrm{H}^{+} / \mathrm{g} \mathrm{dw}$ for MA-9c and FA-2b, respectively. Similarly, $\mathrm{ANC}_{7.5}$, i.e. the point of consumption

365 of carbonates, hydroxides and soluble basic silicate hydrates (Johnson et al., 1995), exhibited clear differences

366 for the two samples: $1.8 \mathrm{meq} \mathrm{H}^{+} / \mathrm{g}$ and $6.4 \mathrm{meq} \mathrm{H}^{+} / \mathrm{g}$ for MA-9c and FA-2b, respectively. This indicated higher

367 contents of carbonates, hydroxides and silicates in the fly ash sample, as confirmed also by the XRD results,

368 which indicated high intensities especially for calcite and portlandite peaks for FA-2b. In line with our findings, 
Freire et al. (2015) reported $\mathrm{ANC}_{4}$ values of 1.2-2.1 meq H $\mathrm{H}^{+} / \mathrm{g} \mathrm{dw}$ and 3.6-9.6 meq $\mathrm{H}^{+} / \mathrm{g} \mathrm{dw}$ for wood BA and wood FA, respectively.

\subsection{2 pH-dependent leaching of major components and nutrients}

373

The pH-dependent leaching of $\mathrm{Na}, \mathrm{K}, \mathrm{Cl}, \mathrm{Ca}, \mathrm{Mg}, \mathrm{Fe}, \mathrm{Si}, \mathrm{Al}$ and $\mathrm{PO}_{4}{ }^{3-}$ is shown as a series of points in Figure 2, together with the results of geochemical model calculations (Model I, see Section 2.6), which are presented as lines. In general, the leaching trends of the major ions were described adequately by the selected mineral phases (see Section 2.6). Most importantly, no significant differences were observed between the leaching trends for FA-2b and MA-9c. Similarly to the leaching observed for other types of thermal residues, such as coal fly ash, MSWI BA and MSWI air pollution control residues (Dijkstra et al., 2006a; Hjelmar, 1990; Hyks et al., 2007), the leaching of $\mathrm{Na}, \mathrm{K}$ and $\mathrm{Cl}$ from the wood ashes was rather independent of $\mathrm{pH}$, while the leached amounts correlated well with those observed from the batch tests at both $\mathrm{L} / \mathrm{S} 2 \mathrm{~L} / \mathrm{kg}$ and $\mathrm{L} / \mathrm{S} 10 \mathrm{~L} / \mathrm{kg}$. However, as also observed here but not captured by geochemical modelling, a slight dependence on $\mathrm{pH}$ for the leaching of $\mathrm{Na}$ and K was shown by Freire et al. (2015) in the case of wood BAs.

\section{<Figure 2>}

Overall, the leaching of other major elements was similar to the leaching observed for MSWI BA and wood ashes. These results are discussed only briefly: $\mathrm{Ca}$ and $\mathrm{Mg}$ showed decreasing releases toward an alkaline pH (Astrup et al., 2006; Dijkstra et al., 2006a; Freire et al., 2015), the release of $\mathrm{SO}_{4}{ }^{2-}$ was relatively pHindependent and Fe and Si increased toward acidic pH values (Astrup et al., 2006; Dijkstra et al., 2006a). Despite the generally low concentration levels of Fe, mostly in the range $0.01-0.1 \mathrm{mg} / \mathrm{L}$, the dissolution of maghemite was observed to describe adequately Fe leaching in the very acidic $(\mathrm{pH} \leq 4)$ and very alkaline $(\mathrm{pH}>11)$ leachates. Leaching of $\mathrm{Al}$ could be approximated by leucite dissolution at $\mathrm{pH}<5$. On the other hand, the leaching of $\mathrm{Al}$ was close to, or below, $\mathrm{LOD}(0.1 \mathrm{mg} / \mathrm{l})$ at $\mathrm{pH}>5$, which is in contrast with relatively high solution concentrations of Al observed in alkaline conditions for MSWI residues (Astrup et al., 2006; Dijkstra et al., 2006a) and other wood ashes (Freire et al., 2015).

Between pH 13 and $\mathrm{pH}$ 8, the leaching of $\mathrm{PO}_{4}{ }^{3-}$ was $\mathrm{pH}$-independent. Below $\mathrm{pH}$ 8, leaching increased by three orders of magnitude toward an acidic $\mathrm{pH}$. Apatite precipitation is likely to occur at neutral to alkaline $\mathrm{pH}$, as also indicated by the positive SI calculated for hydroxyapatite and chlorapatite. The leaching of $\mathrm{Ba}$ 

et al., 2006), which also provided reasonable agreement with the observed Sr leaching (Figure 3).

Similarly to the results provided by Dijkstra et al. (2006a) and Hyks et al. (2007) for MSWI ashes, DOC leaching (Figure S3 in Supplementary Material) was found to be rather independent of pH; however, DOC levels observed for the selected ash samples were up to ten times lower than the values reported in the literature for MSWI ashes despite the high TOC contents observed in both types of wood ash (Table 1). This large discrepancy between "total" and "dissolved" organic carbon is likely caused by the fact that a considerable fraction of TOC consists of elemental carbon (i.e. soot, char formed during incomplete combustion of organic matter), which is abundant in bioash (Bjurström et al., 2014; Vassilev et al., 2013) and relatively insoluble.

\subsection{3 pH-dependent leaching of trace metals and metalloids}

The pH-dependent leaching of $\mathrm{Cd}, \mathrm{Cr}, \mathrm{Cu}, \mathrm{As}, \mathrm{Mo}, \mathrm{Ni}, \mathrm{Pb}, \mathrm{Sb}, \mathrm{Se}, \mathrm{Sr}, \mathrm{V}$ and $\mathrm{Zn}$ is shown as points in Figure 3, while the results of the geochemical modelling are shown as lines. Two types of line are shown for each material, reflecting the results for Model I and Model II (see Section 2.6).

\section{<Figure 3>}

Although Model II generally resulted in a better description of the analytical data, model predictions for Mo and Sb did not respond to the increased amounts of sorption reactive sites. In MSWI BA, the decrease in Mo leaching at $\mathrm{pH}<6$ has been described by the solubility of $\mathrm{CaMoO}_{4(\mathrm{~s})}$ (Dijkstra et al., 2006b); however, including this mineral in our model had no influence on the results. Similarly, although the leaching of Sb decreased toward high $\mathrm{pH}$ values (with a minimum around $\mathrm{pH} 10.5$ - 11), which may indicate the precipitation of several Sb-bearing mineral phase(s) e.g. $\mathrm{Ca}\left[\mathrm{Sb}(\mathrm{OH})_{6}\right]_{2}$, ettringite or roméite (Cornelis et al., 2012), including these minerals in the mineral assemblage had no influence on the modelling results. Model predictions for $\mathrm{Cd}, \mathrm{Mo}, \mathrm{Sb}$ and Se were less accurate, because no suitable mineral phase with the potential to improve model predictions could be identified from speciation calculations or the literature. On the other hand, no thermodynamic data fitting was carried out in either model: the affinity of different ions for sorption sites was not fitted, and the included sorption and DOC complexation models were used in their default setup. Given the available amounts of $\mathrm{Ca}$ and $\mathrm{PO}_{4}{ }^{3-}$, apatite is expected to precipitate in the neutral-alkaline $\mathrm{pH}$ 
Chen et al., 1997a) even in different pH conditions (Chen et al., 1997b). Therefore, we suspect that future model predictions may be improved if a more exhaustive thermodynamic dataset for (hydro-)apatite becomes available.

\subsection{Implications for forestry utilisation}

In Section 2.7, the application of $300 \mathrm{~g} / \mathrm{m}^{2}$ of MA-9c or FA-2b ashes on top of acidic forest soil (pH 3-5) was assumed, and the source-term release from the ash was assumed to be governed by the acidic soil conditions; therefore, ash leaching was estimated based on $\mathrm{pH}-$ dependent results ( $\mathrm{pH} 3-5)$. Ash composition and releases were compared with ten years' worth of atmospheric depositions, and it was assumed that the SQC for "very sensitive land use" had to comply within the very first centimetre of soil (see Figure 4). (in terms of ash dosage) for these materials will likely result in different liming effects, because of the large differences in their ANCs as well as alkaline species content (see Section 3.5.1).

Based on the elemental composition of the ashes, the maximum theoretical loads of $\mathrm{Ba}, \mathrm{Cd}, \mathrm{Cr}, \mathrm{Sr}, \mathrm{Mo}$, $\mathrm{Ni}, \mathrm{Pb}, \mathrm{Sb}, \mathrm{Se}, \mathrm{Sn}$ and $\mathrm{V}$ were always below the selected SQC levels, and above/close to their expected atmospheric deposition over a period of ten years. It is worth noting that because of the higher contents of $\mathrm{Cd}$, Mo, Se, Sn, Sr and Tl in the FA-2b ash, higher loads of these elements should be expected in the case of FA-2b application, compared to MA-9c. Theoretical loads, despite not being necessarily representative of actual ash application, e.g. with the first rainfall, while the source-term release of other macro-/micro- nutrients (e.g. $\mathrm{Cu}, \mathrm{Mg}, \mathrm{Mn}, \mathrm{P}$ and $\mathrm{Zn}$ ) and trace metals may depend on $\mathrm{pH}$. The estimated ash release of $\mathrm{Ca}, \mathrm{K}, \mathrm{Mg}, \mathrm{Mn}$, and $\mathrm{P}$ was of the same order of magnitude as, or higher than, ten years of atmospheric depositions, contrary to the relatively low release of $\mathrm{Al}, \mathrm{Fe}$ and $\mathrm{Na}$. $\mathrm{Ni}, \mathrm{Pb}, \mathrm{Sb}, \mathrm{Se}, \mathrm{Sn}, \mathrm{Tl}$ and $\mathrm{Zn}$, was estimated at levels below, or close to, atmospheric deposition. Similarly, the potential ash release of $\mathrm{Co}, \mathrm{Sr}$ and $\mathrm{V}$ was significantly lower than the selected reference soil levels (Capo et al., 
selected SQC in the case of FA-2b. Remember that FA-2b was selected specifically because of its relatively high Cd content (i.e. $16.3 \mathrm{mg} / \mathrm{kg}$ ), though still within Danish legislation limits (i.e. $20 \mathrm{mg} / \mathrm{kg}$; DEPA (2008)). This supports the notion that the attention paid to $\mathrm{Cd}$ as a potential critical element in wood ashes, because of its potential toxicity and bioavailability (see Introduction), may be justified.

Overall, the results from this study suggested that wood ash utilisation at a dosage of three tonnes per hectare $\left(300 \mathrm{~g} / \mathrm{m}^{2}\right)$ of acidic forest soil does not appear critical compared with atmospheric deposition and SQC. However, high application dosages of wood ash (i.e. largely above three tonnes per hectare) with high Cd contents should be avoided. In general, recirculation of MA and BA may be prioritised over FA, because of the relatively high content (and potential release) of contaminants in this fraction (e.g. $\mathrm{Cd}, \mathrm{Mo}, \mathrm{Se}, \mathrm{Sn}, \mathrm{Sr}$ and $\mathrm{Tl}$ ). Potential soil contamination from PAHs appeared minor, as both contents and source-term releases were observed to be low (below detectable levels in our analyses and well below the SQC levels defined for "very sensitive land use") in the selected ash samples.

While ash leaching is affected by a variety of aspects upon application to forest soils, e.g. redox conditions, interaction with the soil organic matter, sorption, transport, repartitioning, mineralisation and revolatilisation of organic compounds (for more details on the mobility of inorganic compounds into the soil refer to Carter et al. (2009) and Fang et al. (2017), whereas for the organic compounds refer to Aichner et al. (2015), Komprdová et al. (2016) and Obrist et al. (2015)), the above estimations nevertheless offer general insights into the source-term release of nutrients and contaminants onto soil.

\section{CONCLUSIONS}

$\mathrm{Ca}, \mathrm{Si}, \mathrm{P}, \mathrm{K}$ and $\mathrm{Mg}$ abounded in the investigated wood ashes, while relatively high contents of $\mathrm{S}$ and $\mathrm{N}$ were observed in fly ashes and mixed ashes compared with bottom ashes. For some fly ash samples, relatively high contents of $\mathrm{Cd}, \mathrm{Mo}, \mathrm{Se}, \mathrm{Sn}, \mathrm{Sr}$ and $\mathrm{Tl}$ were found. The leaching of most elements changed as a function of the solution $\mathrm{pH}$, except for $\mathrm{K}, \mathrm{Cl}, \mathrm{Na}$ and $\mathrm{SO}_{4}{ }^{2-}$, which were found to be rather independent of $\mathrm{pH}$. While relatively high leaching of $\mathrm{PO}_{4}{ }^{3-}, \mathrm{Mg}, \mathrm{Zn}, \mathrm{Cu}$ and $\mathrm{Cd}$ was observed for $\mathrm{pH}$ conditions relevant to acidic forest soils, $\mathrm{Cr}$ and Mo increased leaching more toward alkaline conditions. For most major, minor and trace elements, leaching was described adequately by a geochemical speciation model based on mineral dissolution involving a relatively limited set of mineral phases. The maximum theoretical loads of $\mathrm{Ba}, \mathrm{Cd}, \mathrm{Cr}, \mathrm{Sr}, \mathrm{Mo}, \mathrm{Ni}, \mathrm{Pb}, \mathrm{Sb}, \mathrm{Se}, \mathrm{Sn}$ and $\mathrm{V}$ were below the selected soil quality criteria levels, whereas the source-term release of $\mathrm{Cd}$ was identified as of 
potential concern compared with these levels. The expected release of nutrients such as $\mathrm{Ca}, \mathrm{Mg}, \mathrm{Mn}, \mathrm{P}$ and $\mathrm{K}$ appeared significant compared to atmospheric deposition. Similar wood ash application rates can result in different liming effects, depending on their alkaline species content. Similar scenario-based assessments of the source-term releases of nutrients and contaminants can be made prior to ash application in specific cases, based on site-specific soil characteristics and information about precipitation.

\section{Acknowledgements}

491 The authors wish to thank Sinh Hy Nguyen, Susanne Kruse, Mikael Emil Olsson and Elisa Allegrini for their

492 technical support in lab related issues and Simon Skov for providing us with the ash samples. The study was supported by the Danish Council for Strategic Research (grant no 0603-00587B) and the Technical University of Denmark and it is part of the ASHBACK project (http://www.ashback.dk/)

\section{REFERENCES}

Aichner, B., Bussian, B.M., Lehnik-habrink, P., Hein, S., 2015. Regionalized concentrations and fi ngerprints of polycyclic aromatic hydrocarbons (PAHs) in German forest soils. Environ. Pollut. 203, 31-39.

Allegrini, E., Maresca, A., Olsson, M.E., Holtze, M.S., Boldrin, A., Astrup, T.F., 2014. Quantification of the resource recovery potential of municipal solid waste incineration bottom ashes. Waste Manag. 34, 1627-

Alther, G.R., Tillman, F.D., Smith, J.A., 2005. Part VIII : Remediation. Evaluation of two Organoclays, Clinoptilolite, and Hydroxy-Apatite As Sorbents for Heavy Metal Removal From Water, in: Calabrese,

Apul, D.S., Diaz, M.E., Gustafsson, J.P., Hundal, L.S., 2010. Geochemical Modeling of Trace Element Release from Biosolids. Environ. Eng. Sci. 27, 743-755. doi:10.1089/ees.2009.0322 E.J.,, Kostecki, P.T.., Dragun, J. (Eds.), Contaminated Soils, Sediments and Water: Science in the Real World. Volume 9. Springer Science + Business Media, Inc., United States of America, pp. 457-468.

Astrup, T., Dijkstra, J.J., Comans, R.N.J., van der Sloot, H., Christensen, T.H., 2006a. Geochemical modeling of leaching from MSWI air-pollution-control residues. Environ. Sci. Technol. 40, 3551-7. doi:10.1021/es052250r

Astrup, T., Mosbaek, H., Christensen, T.H., 2006b. Assessment of long-term leaching from waste incineration 
Balstrøm, T., Breuning-Madsen, H., Krüger, J., Jensen, N.H., Greve, M.H., 2013. A statistically based mapping of the influence of geology and land use on soil pH. A case study from Denmark. Geoderma 192, 453-462. doi:10.1016/j.geoderma.2012.08.024

Bjurström, H., Lind, B.B., Lagerkvist, A., 2014. Unburned carbon in combustion residues from solid biofuels. Fuel 117, 890-899. doi:10.1016/j.fuel.2013.10.020

Bundt, M., Krauss, M., Blaser, P., Wilcke, W., 2001. Forest fertilization with wood ash: effects on the distribution and storage of polycyclic aromatic hydrocarbons (PAHs) and polychlorinated biphenyls (PCBs). J. Environ. Qual. 30, 1296-1304.

Chen, X., Wright, J. V., Conca, J.L., Peurrung, L.M., 1997a. Evaluation of heavy metal remediation using

Chen, X., Wright, J. V., Conca, J.L., Peurrung, L.M., 1997b. Effects of pH on heavy metal sorption on mineral apatite. Environ. Sci. Technol. 31, 624-631. doi:10.1021/es950882f

Cruz-Paredes, C., Wallander, H., Kjøller, R., Rousk, J., 2017. Using community trait-distributions to assign

Dahl, O., Nurmesniemi, H., Pöykiö, R., Watkins, G., 2009. Comparison of the characteristics of bottom ash and fly ash from a medium-size (32 MW) municipal district heating plant incinerating forest residues and peat 
Danish Energy Agency, 2016. Energy statistics 2015 (Energistatistik 2015) [in Danish]. Copenhagen, Denmark.

DEPA, 2015. List of quality criteria in relation to contaminated soil and drinking water. (Miljøministeriet: Liste over kvalitetskriterier i relation til forurenet jord og kvalitetskriterier for drikkevand). [in Danish]. Danish Environmental Protection Agency. doi:10.1002/0471743984.vse9126

DEPA, 2008. BEK $818: 2008$. Statutory Order on the use of bio-ash for agricultural purposes (Bekendtgørelse om anvendelse af bioaske til jordbrugsformål - Bioaskebekendtgørelsen). [in Danish]. Danish Environmental Protection Agency. Copenhagen, Denmark.

DEPA, 1995. Soil quality criteria for selected inorganic compounds. Report n.48, 1995., Danish Environmental Protection Agency. Copenhagen, Denmark.

Dijkstra, J.J., Meeussen, J.C.L., van der Sloot, H., Comans, R.N.J., 2008. A consistent geochemical modelling approach for the leaching and reactive transport of major and trace elements in MSWI bottom ash. Appl. Geochemistry 23, 1544-1562. doi:10.1016/j.apgeochem.2007.12.032

Dijkstra, J.J., van der Sloot, H., Comans, R.N.J., 2006a. The leaching of major and trace elements from MSWI bottom ash as a function of $\mathrm{pH}$ and time. Appl. Geochemistry 21, 335-351. doi:10.1016/j.apgeochem.2005.11.003

Dijkstra, J.J., van Zomeren, A., Meeussen, J.C.L., Comans, R.N.J., 2006b. Effect of accelerated aging of MSWI bottom ash on the leaching mechanisms of copper and molybdenum. Environ. Sci. Technol. 40, 4481-

Drift, A. Van Der, Doorn, J. Van, Vermeulen, J.W., 2001. Ten residual biomass fuels for circulating fluidizedbed gasification. Biomass and Bioenergy 20, 45-56. doi:10.1016/S0961-9534(00)00045-3

Dzombak, D.A., Morel, F.M.M., 1990. Surface complexation modeling: hydrous ferric oxides. John Wiley \& Sons, Inc., New York, NY.

Enell, A., Fuhrman, F., Lundin, L., Warfvinge, P., Thelin, G., 2008. Polycyclic aromatic hydrocarbons in ash: determination of total and leachable concentrations. Environ. Pollut. 152, 285-92. doi:10.1016/j.envpol.2007.06.055

Etiégni, L., Campbell, A.G., 1991. Physical and Chemical Characteristics of Wood Ash. Bioresour. Technol. 37, 173-178. doi:10.1016/0960-8524(91)90207-Z

Etiégni, L., Mahler, R.L., Campbell, a. G., Shafii, B., 1991. Evaluation of wood ash disposal on agricultural 

doi:10.1080/00103629109368413

European Commission, 2015. Statistical Pocketbook 2015. European Union. doi:10.2833/77358

European Commission, 2014. Report on critical raw materials for the EU - Report of the Ad hoc Working Group on defining critical raw materials.

Fang, W., Delapp, R.C., Kosson, D.S., van der Sloot, H.A., Liu, J., 2017. Release of heavy metals during longterm land application of sewage sludge compost: Percolation leaching tests with repeated additions of compost. Chemosphere 169, 271-280. doi:10.1016/j.chemosphere.2016.11.086

Freire, M., Lopes, H., Tarelho, L.A.C., 2015. Critical aspects of biomass ashes utilization in soils: Composition, leachability, PAH and PCDD/F. Waste Manag. 46, 304-315. doi:10.1016/j.wasman.2015.08.036

Fritze, H., Perkiömäki, J., Petänen, T., Pennanen, T., Romantschuk, M., Karp, M., Yrjälä, K., 2001. A microcosmos study on the effects of Cd-containing wood ash on the coniferous humus fungal community and the Cd bioavailability. J. Soils Sediments 1, 146-150. doi:10.1007/BF02986477

Gayer, K.H., Thompson, L.C., Zajicek, O.T., 1958. The solubility of Aluminum Hydroxide in acidic and basic media at 25 C. Can. J. Chem. 36, 1268-1271. doi:10.1139/v58-184

Gayer, K.H., Woontner, L., 1956. The solubility of ferrous hydroxide and ferric hydroxide in acidic and basic media at $25^{\circ}$. J. Phys. Chem. 60, 1569-1571. doi:10.1021/j150545a021

Hjelmar, O., 1990. Leachate from land disposal of coal fly ash. Waste Manag. Res. 8, 429-449. doi:10.1177/0734242X9000800170

Holmberg, S.L., Lind, B.B., Claesson, T., 2000. Chemical composition and leaching characteristics of granules made of wood ash and dolomite. Environ. Geol. 40, 1-10. doi:10.1007/PL00013327

Hovmand, M.F., Kystol, J., 2013. Atmospheric element deposition in southern Scandinavia. Atmos. Environ. 77, 482-489. doi:10.1016/j.atmosenv.2013.03.008

Huang, H., Campbell, A.G., Folk, R., Mahler, R.L., 1992. Wood ash as a soil additive and liming agent for wheat: Field studies. Commun. Soil Sci. Plant Anal. 23, 25-33. doi:10.1080/00103629209368567

Hyks, J., Astrup, T., Christensen, T.H., 2009. Leaching from MSWI bottom ash: evaluation of non-equilibrium in column percolation experiments. Waste Manag. 29, 522-9. doi:10.1016/j.wasman.2008.06.011

Hyks, J., Astrup, T., Christensen, T.H., 2007. Influence of test conditions on solubility controlled leaching predictions from air-pollution-control residues. Waste Manag. Res. 25, 457-466. 
Ingerslev, M., Hansen, M., Pedersen, L.B., Skov, S., 2014. Effects of wood chip ash fertilization on soil chemistry in a Norway spruce plantation on a nutrient-poor soil. For. Ecol. Manage. 334, 10-17. doi:10.1016/j.foreco.2014.08.034

605

Ingerslev, M., Skov, S., Sevel, L., Pedersen, L.B., 2011. Element budgets of forest biomass combustion and ash

606

607

608

609

610

611

612

613

614

615

616

617

618

619

620

621

622

623

624

625

626

627

628

fertilisation - A Danish case-study. Biomass and Bioenergy 35, 2697-2704. doi:10.1016/j.biombioe.2011.03.018

Johansson, I., van Bavel, B., 2003. Levels and patterns of polycyclic aromatic hydrocarbons in incineration ashes. Sci. Total Environ. 311, 221-31. doi:10.1016/S0048-9697(03)00168-2

Johnson, C. a, Brandenberger, S., Baccini, P., 1995. Acid neutralizing capacity of municipal waste incinerator bottom ash. Environ. Sci. Technol. 29, 142-7. doi:10.1021/es00001a018

Karltun, E., Saarsalmi, A., Ingerslev, M., Mandre, M., Andersson, S., Gaitnieks, T., State, L., 2008. 4. Wood ash recycling - Possibilities and risks, in: Röser, D., Asikainen, A., Raulund-Rasmussen, K., Stupak, I. (Eds.), Sustainable Use of Forest Biomass for Energy. pp. 79-108.

Kinniburgh, D.G., Milne, C.J., Benedetti, M.F., Pinheiro, J.P., Filius, J., Koopal, L.K., Van Riemsdijk, W.H., 1996. Metal Ion Binding by Humic Acid: Application of the NICA-Donnan Model. Environ. Sci. Technol. 30, 1687-1698. doi:10.1021/es950695h

Komprdová, K., Men, L., Va, L., Nizzetto, L., 2016. The influence of tree species composition on the storage and mobility of semivolatile organic compounds in forest soils. Sci. Total Environ. 553, 532-540. doi:10.1016/j.scitotenv.2016.02.132

Kosson, D.S., van der Sloot, H., Eighmy, T.T., 1996. An approach for estimation of contaminant release during utilization and disposal of municipal solid waste combustion residues. J. Hazard. Mater. 47, 43-75. doi:10.1016/0304-3894(95)00109-3

Lanzerstorfer, C., 2015. Chemical composition and physical properties of filter fly ashes from eight grate-fired biomass combustion plants. J. Environ. Sci. 30, 191-197. doi:10.1016/j.jes.2014.08.021

Liodakis, S., Tsoukala, M., Katsigiannis, G., 2009. Laboratory Study of Leaching Properties of Mediterranean Forest Species Ashes. Water. Air. Soil Pollut. 203, 99-107. doi:10.1007/s11270-009-9994-y

Magdziarz, A., Dalai, A.K., Koziński, J.A., 2016. Chemical composition, character and reactivity of renewable fuel ashes. Fuel 176, 135-145. doi:10.1016/j.fuel.2016.02.069 
Masto, R.E., Sarkar, E., George, J., Jyoti, K., Dutta, P., Ram, L.C., 2015. PAHs and potentially toxic elements in the fly ash and bed ash of biomass fired power plants. Fuel Process. Technol. 132, 139-152. doi:10.1016/j.fuproc.2014.12.036

Meeussen, J.C.L., 2003. ORCHESTRA: An Object-Oriented Framework for Implementing Chemical Equilibrium Models. Environ. Sci. Technol. 37, 1175-1182. doi:10.1021/es025597s

Mellbo, P., Sarenbo, S., Stålnacke, O., Claesson, T., 2008. Leaching of wood ash products aimed for spreading in forest floors - Influence of method and L/S ratio. Waste Manag. 28, 2235-44. doi:10.1016/j.wasman.2007.09.037

Milne, C.J., Kinniburgh, D.G., van Riemsdijk, W.H., Tipping, E., 2003. Generic NICA-Donnan model parameters for metal-ion binding by humic substances. Environ. Sci. Technol. 37, 958-71. doi:10.1021/es0258879

Narodoslawsky, M., Obernberger, I., 1996. From waste to raw material -the route from biomass to wood ash for cadmium and other heavy metals. J. Hazard. Mater. 50, 157-168. doi:10.1016/0304-3894(96)01785-2

Nordtest TR576 (2004), 2004. Leaching tests for non-volatile organic compounds - development and testing (NT TR 576).

Obrist, D., Zielinska, B., Perlinger, J.A., 2015. Accumulation of polycyclic aromatic hydrocarbons (PAHs) and oxygenated PAHs (OPAHs) in organic and mineral soil horizons from four U . S . remote forests. Chemosphere 134, 98-105. doi:10.1016/j.chemosphere.2015.03.087

Perkiömäki, J., Fritze, H., 2005. Cadmium in upland forests after vitality fertilization with wood ash - A summary of soil microbiological studies into the potential risk of cadmium release. Biol. Fertil. Soils 41, 75-84. doi:10.1007/s00374-004-0816-5

Pitman, R.M., 2006. Wood ash use in forestry - a review of the environmental impacts. Forestry 79, 563-588. doi:10.1093/forestry/cpl041

Pöykiö, R., Mäkelä, M., Nurmesniemi, H., Dahl, O., Oguchi, M., 2012. Application of the BRC Sequential 

Sized (115 MW) Industrial Power Plant of a Pulp and Board Mill. Waste and Biomass Valorization 4, 821-830. doi:10.1007/s12649-012-9170-2

Pöykiö, R., Nurmesniemi, H., Dahl, O., 2007. Concentrations of nutrients and heavy metals in cyclone fly ash from the grate-fired boiler at a small municipal district heating plant (6 MW). J. Residuals Sci. Technol. doi:http://dx.doi.org/10.1016/j.jhazmat.2008.05.140

Pöykiö, R., Rönkkömaki, H., Nurmesniemi, H., Peramaki, P., Popov, K., Valimaki, I., Tuomi, T., 2009. Chemical and physical properties of cyclone fly ash from the grate-fired boiler incinerating forest residues

Reflab 4:2008, 2008. Determination of hydrocarbons, BTEX and PAH in soil by gas chromatography. (Bestemmelse af kulbrinter, BTEX og PAH i jord ved gaskromatografi).[in Danish]. Styrelsen for Vandog Naturforvaltnings Referencelaboratorium for Kemiske og Mikrobiologiske Miljø. Denmark.

672 at a small municipal district heating plant (6MW). J. Hazard. Mater. 162, 1059-64.

Sano, T., Miura, S., Furusawa, H., Kaneko, S., Yoshida, T., Nomura, T., Ohara, S., 2013. Composition of

Sarenbo, S., 2009. Wood ash dilemma-reduced quality due to poor combustion performance. Biomass Bioenergy 33, 1212-1220. doi:10.1016/j.biombioe.2009.05.007

Skov, S., Ingerslev, M., 2013. Wood ash in practice (Flisaske i praksis). [in Danish]. Institut for Geovidenskab og Naturforvaltning - Københavns Universitet. Frederiksberg, Denmark. Document]. URL http://woodash.slu.se/eng/stats.cfm (accessed 8.22.16). wood ash. Doktorsavhandlingar Vid Chalmers Tek. Hogsk. fuel - Effects on fly ash properties. Fuel 89, 2026-2032. doi:10.1016/j.fuel.2010.02.006 
Steenari, B.M., Karlsson, L.G., Lindqvist, O., 1999. Evaluation of the leaching characteristics of wood ash and the influence of ash agglomeration. Biomass and Bioenergy 16, 119-136. doi:10.1016/S09619534(98)00070-1

Straka, P., Havelcová, M., 2012. Polycyclic aromatic hydrocarbons and other organic compounds in ashes from biomass combustion. ACTA Geodyn. Geomater. 9, 481-490.

Supancic, K., Obernberger, I., Kienzl, N., Arich, A., 2014. Conversion and leaching characteristics of biomass ashes during outdoor storage - Results of laboratory tests. Biomass and Bioenergy 61, 211-226. doi:10.1016/j.biombioe.2013.12.014

The Danish Council on Climate Change, 2015. Converting with care: Status and challenges for Danish climate policy.

US EPA, 2008. Polycyclic Aromatic Hydrocarbons (PAHs), United States - Environmental Protection Agency. Washington, DC 20460.

van der Sloot, H., van Zomeren, A., 2010. Geochemical speciation modelling of $\mathrm{pH}$ dependence test data as alternative to sequential chemical extraction, in: Proceedings Venice 2010, Third International Symposium on Energy from Biomass and Waste.

van Eijk, R.J., Obernberger, I., Supancic, K., 2012. Options for increased utilization of ash from biomass combustion and co-firing. Report (KEMA). Arnhem, The Netherlands.

Vassilev, S. V., Baxter, D., Andersen, L.K., Vassileva, C.G., 2013. An overview of the composition and application of biomass ash. Part 1. Phase-mineral and chemical composition and classification. Fuel 105, 40-76. doi:10.1016/j.fuel.2012.09.041

Vassilev, S. V., Vassileva, C.G., Baxter, D., 2014. Trace element concentrations and associations in some biomass ashes. Fuel 129, 292-313. doi:10.1016/j.fuel.2014.04.001

Vehlow, J., Dalager, S., 2011. 8.2 Incineration: Flue Gas Cleaning and Emissions, in: Christensen, T.H. (Ed.), Solid Waste Technology \& Management. Blackwell Publishing Ltd, pp. 393-420.

Werkelin, J., Lindberg, D., Bostrom, D., Skrifvars, B.J., Hupa, M., 2011. Ash-forming elements in four Scandinavian wood species part 3: Combustion of five spruce samples. Biomass and Bioenergy 35, 725733. doi:10.1016/j.biombioe.2010.10.010 
716 Table 1. Composition of wood ash samples in comparison with typical literature values (primarily from grate-

717 fired wood ashes), grouped by ash type (BA, FA and MA). Minimum and maximum contents within each ash

718 group are reported. Results are expressed in $\mathrm{mg} / \mathrm{kg} \mathrm{dw}$, unless differently specified. [n.m.: not measured; MC:

719 moisture content; TOC: total organic carbon].

\begin{tabular}{ccccccc}
\hline & BA - this study & BA - literature ${ }^{\text {a) }}$ & FA - this study & FA - literature ${ }^{\text {a) }}$ & MA - this study & MA - literature ${ }^{\text {a) }}$ \\
\hline samples & BA- 1, 2, & & FA- 1, 2a, 2b, 3 & & MA- $4,5,6,7,8$, & $9 \mathrm{a}, 9 \mathrm{~b}, 9 \mathrm{c}, 10$ \\
\\
MC [\%] & $8.07-29.5$ & $19-31$ & $28.1-60.2$ & $0.2-52$ & $0.0672-54.5$ & n.m. \\
TOC [\%] & $0.639-2.85$ & $<0.05$ & $7.39-32.8$ & 1.6 & $0.472-19.1$ & $0.52-13$ \\
NUTRIENTS AND MAJOR COMPONENTS & & & & \\
\hline
\end{tabular}

$\begin{array}{cc}\text { Al } & 14300-16800 \\ \mathbf{C a} & 79400-162000 \\ \mathbf{C l} & \text { n.m. } \\ \mathbf{C u} & 64.6-111 \\ \mathbf{F e} & 4610-6570 \\ \mathbf{K} & 35800-73200 \\ \mathbf{M g} & 16500-20600 \\ \mathbf{M n} & 3470-19400 \\ \mathbf{N} & <400 \\ \mathbf{N a} & 8260-11100 \\ \mathbf{P} & 8310-17400 \\ \mathbf{S} & 153-967 \\ \mathbf{S i} & 208000-273000 \\ \mathbf{Z n} & 73.9-234\end{array}$

$\begin{array}{ccc}16000-40000 & 5920-11800 & 3600-26000 \\ 130000-300000 & 104000-263000 & 120000-280000 \\ <20-4700 & \text { n.m. } & 1600-11000 \\ 69-200 & 106-161 & 140-1100 \\ 6000-26000 & 2880-8300 & 1500-59000 \\ 40000-47000 & 40000-60300 & 50000-160000 \\ 12000-44000 & 19300-32900 & 20000-50000 \\ 4300-27000 & 4030-30300 & 1300-23000 \\ 150 & 1670-4930 & 2500-2500 \\ 4800-12000 & 6650-12000 & 3100-8300 \\ 7200-22000 & 10200-22900 & 4300-20000 \\ 270-2400 & 4210-15300 & 5800-25000 \\ 120000-250000 & 45600-124000 & 11000-82000 \\ 65-950 & 446-1120 & 370-40000\end{array}$

$\begin{array}{cc}9020-16500 & 1700-40000 \\ 75600-214000 & 24000-340000 \\ \text { n.m. } & 210-14000 \\ 71.4-195 & 78-440 \\ 5000-15000 & 1600-25000 \\ 35800-80000 & 25000-250000 \\ 12800-39900 & 16000-80000 \\ 3060-19000 & 3500-19000 \\ <400-2600 & 600-5000 \\ 6590-11300 & 500-37000 \\ 10000-26500 & 3200-21000 \\ 1540-5950 & 1300-52000 \\ 124000-271000 & 17000-260000 \\ 18.4-737 & 26-2800\end{array}$

TYPICAL ELEMENTS OF ENVIRONMENTAL CONCERN

\begin{tabular}{|c|c|c|c|c|c|c|}
\hline As & $2.17-3.19$ & 1.4 & $2.68-6.98$ & $1.5-24$ & $2.24-7.67$ & $0.09-74$ \\
\hline $\mathbf{B a}$ & $802-1400$ & $1600-2200$ & $797-2320$ & $1200-4300$ & $684-1880$ & $420-2700$ \\
\hline Cd & $0.158-0.467$ & $<0.2-5.7$ & $7.32-16.3$ & $5.1-34$ & $0.109-8.82$ & $<2-31$ \\
\hline Co & $4.23-7.3$ & $6.7-11$ & $5.79-9.69$ & $11-13$ & $3.76-7.72$ & $<3-77$ \\
\hline $\mathrm{Cr}$ & $24.9-69.5$ & $64-320$ & $26.5-62.7$ & $32-290$ & $22-217$ & $14-260$ \\
\hline $\mathrm{Hg}$ & n.m. & $0.02-0.1$ & n.m. & 1.7 & n.m. & $0.06-1.2$ \\
\hline Mo & $1.06-1.84$ & $1-5.8$ & $1.46-4.29$ & $8.6-16$ & $1.14-4.36$ & $1.2-120$ \\
\hline $\mathbf{N i}$ & $27.4-38.6$ & $22-200$ & $22.4-52.5$ & $19-74$ & $31.2-44.7$ & $12-500$ \\
\hline $\mathbf{P b}$ & $4.74-79.8$ & $4-40$ & $10.7-73.8$ & $25-470$ & $0.682-36.4$ & $13-130$ \\
\hline $\mathbf{S b}$ & $0.496-3.48$ & $0.86-2.3$ & $0.721-5.83$ & $1.7-3$ & $0.69-3.11$ & $0.71-94$ \\
\hline Se & $<16.7$ & $<0,1$ & $<16.7$ & $0.24-2.1$ & $<16.7$ & 16 \\
\hline Sn & $<0.305-1$ & $11-16$ & $1.21-6.37$ & $15-22$ & $1.07-3.14$ & $2.1-4.4$ \\
\hline $\mathrm{Sr}$ & $466-783$ & $610-710$ & $578-1240$ & $750-2100$ & 449 - 959 & $320-1200$ \\
\hline $\mathbf{T l}$ & $0.172-0.473$ & n.m. & $0.975-1.98$ & n.m. & $0.0624-1.49$ & n.m. \\
\hline $\mathbf{V}$ & $10.4-18.4$ & $26-64$ & $6.75-18.2$ & $5.1-43$ & $11.3-18.6$ & $3.4-56$ \\
\hline
\end{tabular}

$721{ }^{a}$ : Etiégni and Campbell (1991); Etiegni et al. (1991); Holmberg et al. (2000); Huang et al. (1992); Ingerslev et 722 al. (2014); Narodoslawsky and Obernberger (1996); Poykio et al. (2007); Pöykiö et al. (2009); SLU (2008);

723 Steenari et al. (1999); Supancic et al. (2014); Vassilev et al. (2014b). 
724 Table 2. Compliance leaching test results in comparison with literature values, grouped by ash type (BA, FA and

725 MA). Results are expressed in $\mathrm{mg} / \mathrm{kg} \mathrm{dw}$, unless differently specified. Minimum and maximum contents within

726 each ash group are reported. Leaching tests were carried out at the L/S ratio 2 L/kg (EN 12457-1:2002) and 10

727 L/kg (EN 12457-3:2002). [n.m.: not-measured; * : indicates that the value only refers to FA-2b or MA-9c].

\begin{tabular}{|c|c|c|c|c|c|c|c|}
\hline & $\begin{array}{c}\text { BA } \\
(\mathbf{L} / \mathbf{S} 2)\end{array}$ & $\begin{array}{c}\text { FA } \\
(\mathbf{L} / \mathbf{S} 2)\end{array}$ & $\begin{array}{c}\text { FA } \\
\text { (L/S 10) }\end{array}$ & $\begin{array}{c}\text { MA } \\
(\text { L/S 2) } \\
\end{array}$ & $\begin{array}{c}\text { MA } \\
(\text { L/S 10) } \\
\end{array}$ & $\begin{array}{c}\text { BA- Literature a) } \\
\text { (L/S 10) }\end{array}$ & $\begin{array}{c}\text { FA- Literature }{ }^{\text {a) }} \\
\text { (L/S 10) }\end{array}$ \\
\hline samples & BA- $1,2,3$ & FA- $2 a, 2 b$ & FA-2b & $\begin{array}{c}\text { MA- } 4,5,6,7,8 \\
\text { 9a, 9b, 9c, } 10\end{array}$ & MA-9c & 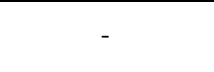 & 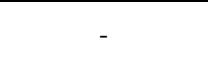 \\
\hline pH [-] & $12.9-13.3$ & $13.1-13.9$ & 12.7 & $11.9-13.8$ & 12.7 & $10.7-13.5$ & $11.9-13$ \\
\hline $\mathbf{E C}[\mathrm{mS} / \mathrm{cm}]$ & $12-43$ & $64-69$ & 19.9 & $9.2-67$ & 14.3 & $1.466-15.88$ & 3.7 \\
\hline DOC & $68-120$ & $78-160$ & 86 & $6.6-630$ & 12 & - & $0.192-29$ \\
\hline \multicolumn{8}{|c|}{ NUTRIENTS AND MAJOR COMPONENTS } \\
\hline Al & $0.72-8.6$ & $<0.25$ & $<1.2$ & $<0.25-24$ & $<1.2$ & $<1-35$ & 5.3 \\
\hline $\mathbf{C a}$ & $22-220$ & $16-320$ & 4700 & $<8-1500$ & 7000 & $100-8980$ & $2700-10790$ \\
\hline $\mathbf{C l}$ & $77-320$ & $2500-3400$ & 3200 & $84-3600$ & 750 & $1.21-800$ & $7000-34000$ \\
\hline $\mathrm{Cu}$ & $0.013-0.23$ & $0.025-0.15$ & 0.066 & $<0.0043-0.55$ & $<0.021$ & $0.03-<0.5$ & $0.08-<0.5$ \\
\hline $\mathbf{F e}$ & $<0.012$ & $<0.013$ & $<0.062$ & $<0.017$ & $<0.062$ & $0.03-<0.5$ & $0.034-<0.5$ \\
\hline $\mathbf{K}$ & $2700-14000$ & $25000-29000$ & 28000 & $4400-39000$ & 9500 & $384-14200$ & $3413-30000$ \\
\hline Mg & $<0.032$ & $<0.034$ & 0.26 & $<0.032-1.5$ & 0.43 & $<0.2-3$ & $<0.2-2.35$ \\
\hline Mn & $0.011-0.065$ & $<0.011-0.018$ & $<0.053$ & $<0.011-0.46$ & $<0.053$ & $0.02-0.14$ & $0.009-<0.2$ \\
\hline $\mathbf{N a}$ & $280-1000$ & $2200-3500$ & 2400 & $340-4100$ & 1000 & $42-204$ & $700-6000$ \\
\hline $\mathbf{P}$ & $<0.59-1.2$ & $<0.61$ & $<2.9$ & $<0.59-1.6$ & $<2.9$ & $<5$ & 0.13 \\
\hline $\mathbf{S}$ & & $1700 *$ & $1600^{*}$ & $420^{*}$ & $410^{*}$ & $7-1040$ & $500-16700$ \\
\hline $\mathbf{S i}$ & $<0.35-230$ & $<0.36-3.3$ & $<1.8$ & $<0.35-570$ & $<1.8$ & $<10-122$ & $5.6-38$ \\
\hline $\mathbf{Z n}$ & $<0.063$ & $0.24-0.38$ & 0.31 & $<0.067-1.9$ & 2.8 & $<0.2$ & $<0.2-51$ \\
\hline \multicolumn{8}{|c|}{ TYPICAL ELEMENTS OF ENVIRONMENTAL CONCERN } \\
\hline As & $<0.0044-0.048$ & $<0.0046-0.005$ & $<0.022$ & $<0.0044-0.61$ & $<0.022$ & $<5$ & 0.044 \\
\hline Ba & $0.059-1.4$ & $0.22-0.59$ & 2.9 & $0.015-0.75$ & 5.9 & $1.27-131$ & $2.7-145$ \\
\hline Cd & $<0.0014$ & $<0.0014$ & $<0.007$ & $<0.0015$ & $<0.0069$ & $<0.03$ & $0.0004-<0.02$ \\
\hline Co & $<0.001-0.0024$ & $<0.001-0.0032$ & $<0.005$ & $<0.001-0.023$ & $<0.005$ & $<0.2$ & $0.001-0.001$ \\
\hline $\mathbf{C r}$ & $0.13-5.7$ & $1.2-6.2$ & 6.2 & $<0.0046-4.5$ & 0.29 & $0.08-0.91$ & $0.01-38$ \\
\hline $\mathbf{H g}$ & n.m. & n.m. & n.m. & n.m. & n.m. & - & - \\
\hline Mo & $0.25-0.38$ & $0.46-1.1$ & 1.1 & $0.25-1.7$ & 0.26 & $<0.2$ & $0.78-5.4$ \\
\hline $\mathbf{N i}$ & $0.03-0.067$ & $<0.0046-0.28$ & 1.1 & $0.023-0.87$ & 0.94 & $<0.5$ & $0.009-<0.5$ \\
\hline $\mathbf{P b}$ & $<0.0013-0.014$ & $0.011-0.054$ & 0.09 & $<0.0014-0.021$ & 0.036 & $0.11-<0.5$ & $<0.5-157$ \\
\hline $\mathbf{S b}$ & $<0.0024-0.0035$ & $<0.0025$ & $<0.012$ & $<0.0024-0.11$ & $<0.012$ & - & $<0.05-0.18$ \\
\hline Se & $<0.014-0.027$ & $0.23-0.68$ & 0.34 & $0.053-0.54$ & 0.2 & - & $0.14-1.5$ \\
\hline Sn & $<0.0025$ & $<0.0026$ & $<0.012$ & $<0.0025-0.006$ & $<0.012$ & - & $0.004-0.004$ \\
\hline $\mathrm{Sr}$ & $0.1-3.8$ & $3.3-11$ & 56 & $0.073-26$ & 61 & - & 33 \\
\hline Tl & $<0.00036-0.00078$ & $<0.00037$ & $<0.0018$ & $<0.00036-0.0008$ & $<0.0018$ & - & - \\
\hline $\mathbf{V}$ & $0.0019-0.51$ & $0.0019-0.0019$ & $<0.0073$ & $<0.0015-3.2$ & $<0.0073$ & $<0.1$ & 0.035 \\
\hline
\end{tabular}

729 a): Freire et al. (2015); Pöykiö et al. (2009); Steenari and Karlfeldt Fedje (2010); Supancic et al. (2014); Van Der $730 \quad$ Sloot and Van Zomeren (2010). 

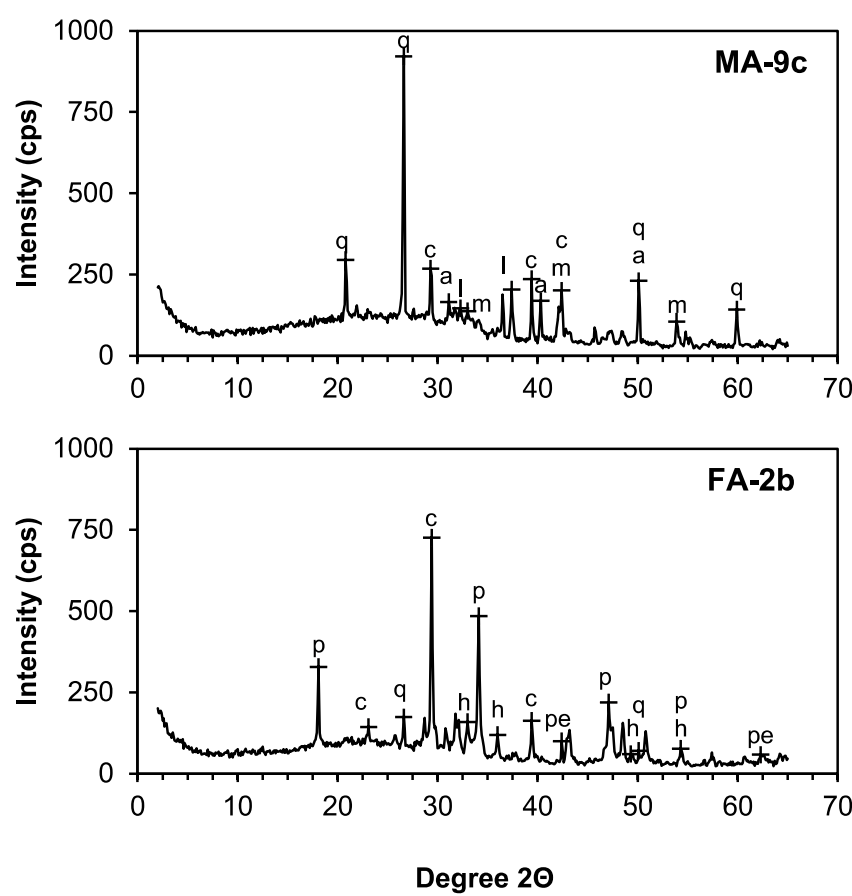

Figure 1. XRD patterns for samples MA- $9 \mathrm{c}$ and FA- $2 \mathrm{~b}$ and mineral phase identification. [a: ankerite; $c$ : calcite;

734 h: hematite; m: magnesite; p: portlandite; pe: periclase; q: quartz; s: calcium silicate; 1: lime]. 

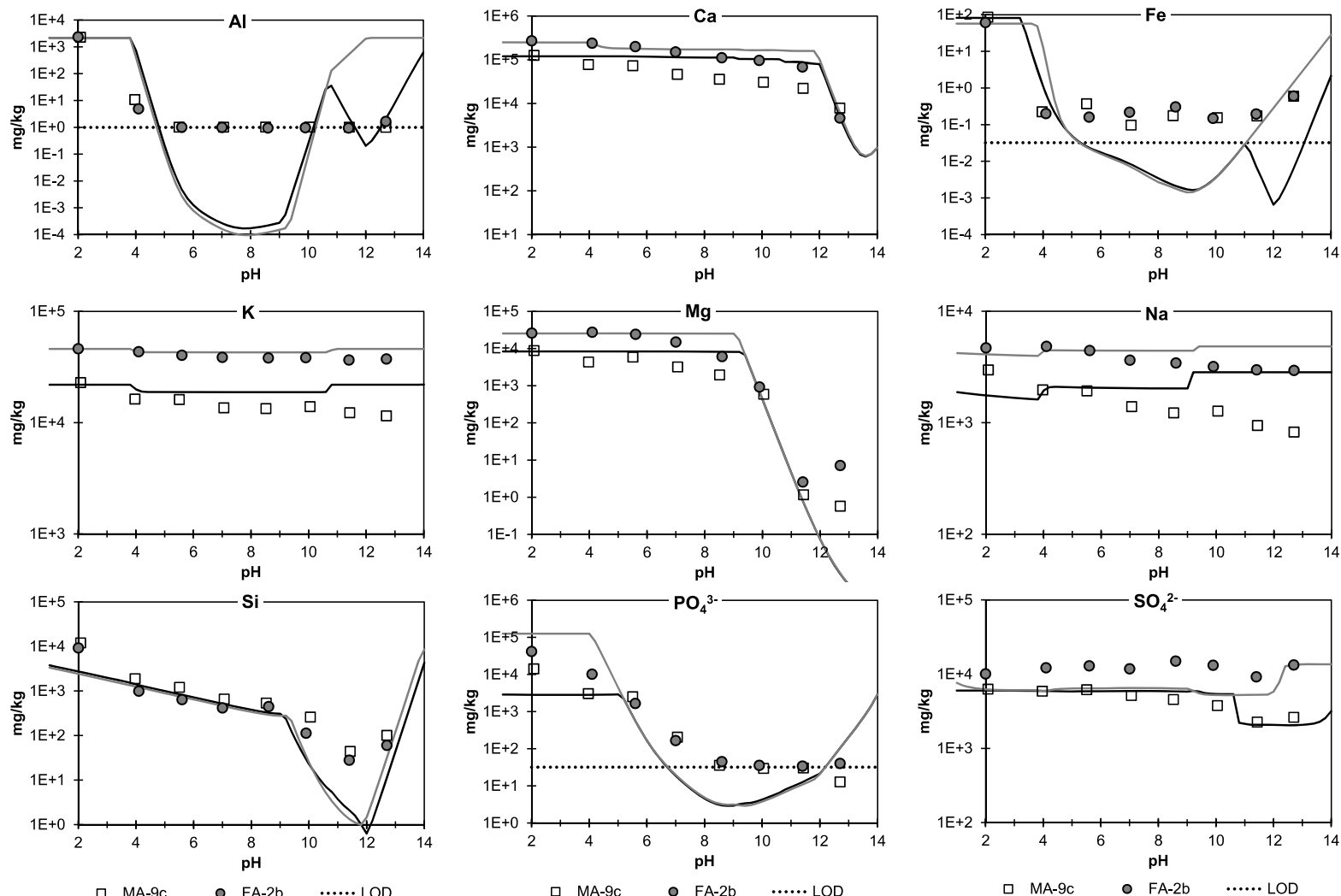

737 Figure 2. pH-dependent leaching test results in comparison with the geochemical model predictions: major components and nutrients. The results are expressed as leached amount (in $\mathrm{mg} / \mathrm{kg} \mathrm{dw}$ ). Dots and squares series represent measured values for FA-2b and MA-9c, respectively. Full lines represent Model I (m I) predictions. [LOD: limit of detection] 

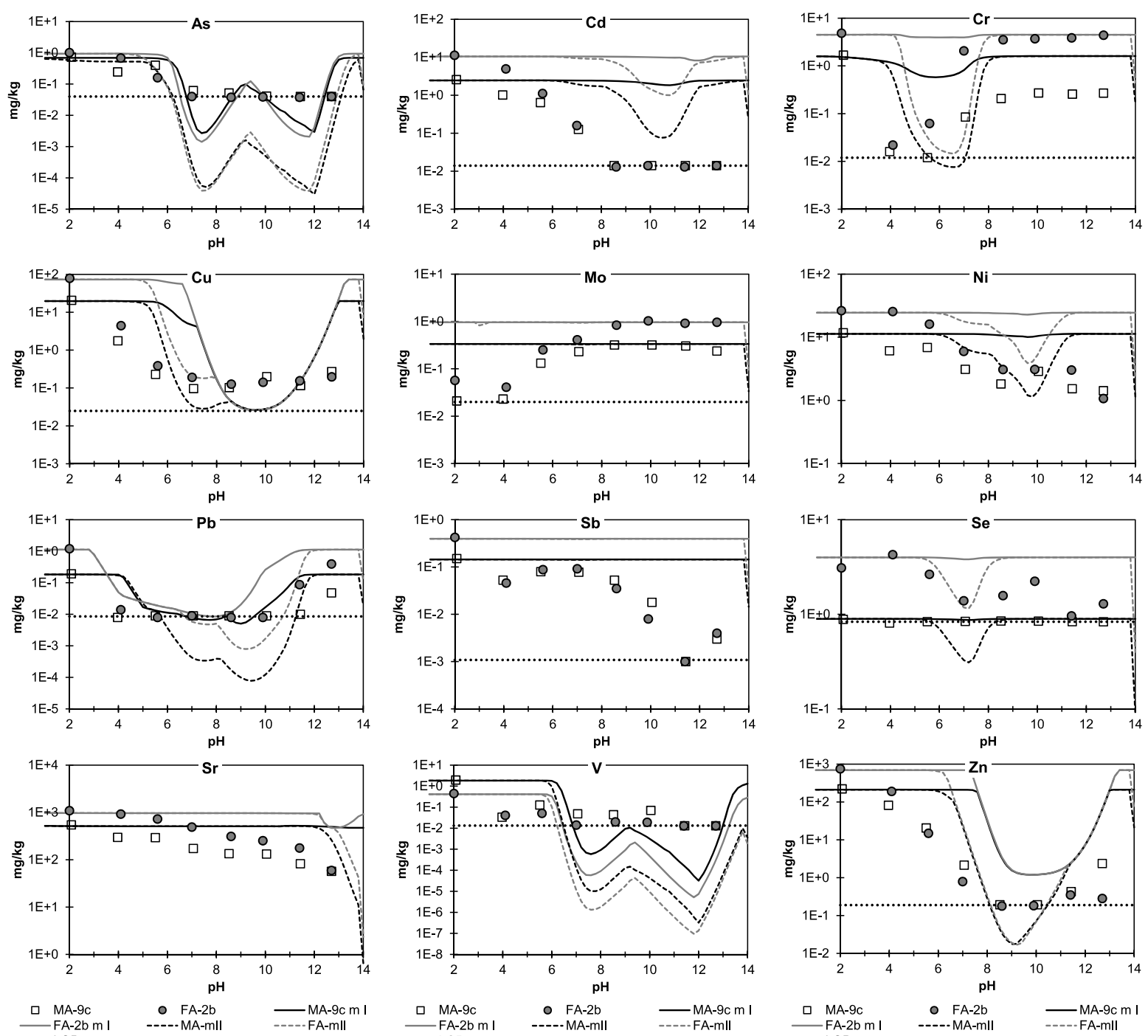

\begin{tabular}{llll} 
口 MA-9c & $\circ$ FA-2b & $\longrightarrow$ MA-9cm I \\
\hline FA-2b m I & $-\cdots$ MA-mll & $---\cdot$ FA-mll
\end{tabular}

\begin{tabular}{lll} 
MA-9c & O FA-2b & $\longrightarrow$ MA-9c $m$ I \\
\hline & FA-2b $m$ I & $-\cdots$ MA-mll
\end{tabular}

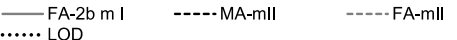

743 Figure 3. $\mathrm{pH}$-dependent leaching test results in comparison with the geochemical model predictions: trace metals

744 and metalloids. The results are expressed as leached amount (in $\mathrm{mg} / \mathrm{kg} \mathrm{dw}$ ). Dots and squares series represent measured values for FA-2b and MA-9c, respectively. Full lines represent Model I (m I) predictions, whereas dashed lines represent Model II (m II) predictions. [LOD: limit of detection] 


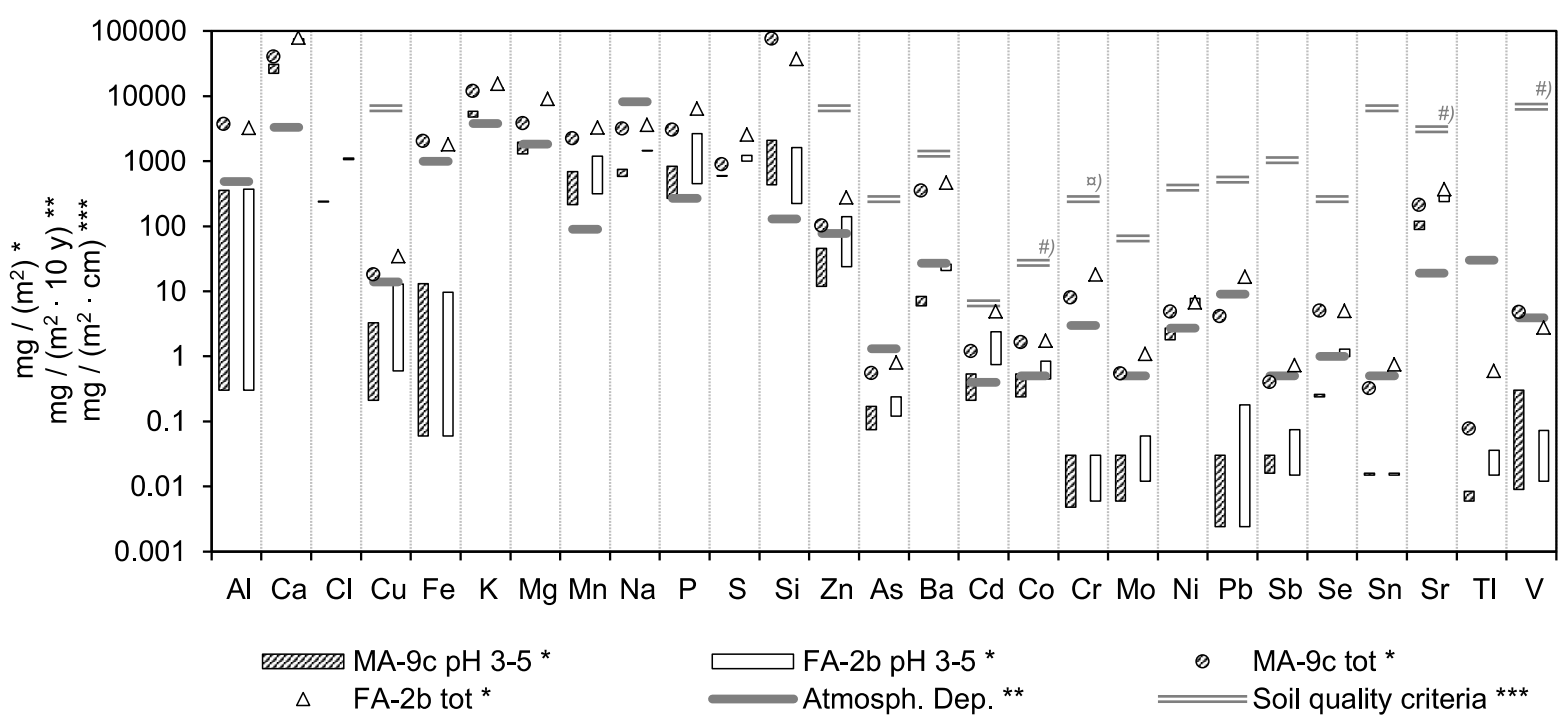

Figure 4. Composition and source-term release of the two selected ash samples, i.e. MA-9c and FA-2b, in comparison with ten years' worth of Danish atmospheric deposition (Hovmand and Kystol, 2013) and Danish SQC for "very sensitive land use" (DEPA, 2015), assuming an ash dosage of $300 \mathrm{~g} / \mathrm{m}^{2}$ and that the SQC had to comply within the first centimetre of soil (soil density of 1.1-1.5 $\mathrm{g} / \mathrm{cm}^{3}$ ). Ash release data reflect the observed leaching from $\mathrm{pH}$-dependent tests at the $\mathrm{pH}$ 3-5. [ a $)$ : soil quality criteria for $\mathrm{Cr}$ refers to $\mathrm{Cr}$ (VI) only; \#): soil values for Co, Sr and V refer to typical Danish farmland contents (DEPA, 1995), average mineral soil composition (Capo et al., 1998), and California Human Health Screening Levels in the case of a residential scenario (OEHHA, 2010), respectively]. 


\section{Recirculation of biomass ashes onto forest soils: ash}

a) Technical University of Denmark, Department of Environmental Engineering, Building 113, 
Table S1. Wood ash samples and combustion facilities: main characteristics.

\begin{tabular}{ccccc}
\hline Sample & Ash type & $\begin{array}{c}\text { Combustion } \\
\text { plant }\end{array}$ & $\begin{array}{c}\text { Combustion } \\
\text { technology }\end{array}$ & $\begin{array}{c}\text { Use of wood chips } \\
\text { period: 2014- 2015 } \\
\text { tonnes wood chips /year) }\end{array}$ \\
\hline BA-1 & Bottom & Ebeltoft (I) & Grate fired & 11000 \\
BA-2 & Bottom & Ebeltoft (II) & Grate fired & 9000 \\
BA-3 & Bottom & Herning & Grate fired & 252000 \\
FA-1 & Fly & Ebeltoft (I) & Grate fired & 18000 \\
FA-2a & Fly & Ebeltoft (II) & Grate fired & 11000 \\
FA-2b & Fly & Ebeltoft (II) & Grate fired & 9000 \\
FA-3 & Fly & Herning & Grate fired & 252000 \\
MA-4 & Mixed & Trustrup & Grate fired & 4500 \\
MA-5 & Mixed & Allingåbro & Grate fired & 5000 \\
MA-6 & Mixed & Kjellerup & Grate fired & 17000 \\
MA-7 & Mixed & Assens J & Grate fired & 5500 \\
MA-8 & Mixed & Galten & Grate fired & 14900 \\
MA-9a & Mixed & Brande & Grate fired & 8500 \\
MA-9b & Mixed & Brande & Grate fired & 8500 \\
MA-9c & Mixed & Brande & Grate fired & 8500 \\
MA-10 & Mixed & Harboør & Gasification & 9000 \\
\hline
\end{tabular}

783 Table S2. List of mineral phases identified in this study, both from XRD analyses and geochemical modelling.

\begin{tabular}{|c|c|}
\hline Mineral Name & Chemical formula \\
\hline Ankerite & $\mathrm{Ca}(\mathrm{Fe}, \mathrm{Mg}, \mathrm{Mn})\left(\mathrm{CO}_{3}\right)_{2}$ \\
\hline $\mathrm{Ba}_{0.5} \mathrm{Sr}_{0.5} \mathrm{So}_{4}$ & $\mathrm{Ba}_{0.5} \mathrm{Sr}_{0.5} \mathrm{SO}_{4}$ \\
\hline Birnessite & $\left(\mathrm{Na}_{0.3} \mathrm{Ca}_{0.1} \mathrm{~K}_{0.1}\right)\left(\mathrm{Mn}^{4+}, \mathrm{Mn}^{3+}\right)_{2} \mathrm{O}_{4} \cdot 1.5 \mathrm{H}_{2} \mathrm{O}$ \\
\hline Brucite & $\mathrm{Mg}(\mathrm{OH})_{2}$ \\
\hline Calcite & $\mathrm{CaCO}_{3}$ \\
\hline Calcium silicate & $\mathrm{Ca}_{2} \mathrm{O}_{4} \mathrm{Si}$ \\
\hline Calcium silicate hydrates & $\begin{array}{l}\text { examples: } \\
\text { Tobermorite: } \mathrm{Ca}_{5} \mathrm{Si}_{6} \mathrm{O}_{16}(\mathrm{OH})_{2} \cdot 4 \mathrm{H}_{2} \mathrm{O} \text {; Jennite: } \mathrm{Ca}_{9} \mathrm{Si}_{6} \mathrm{O}_{18}(\mathrm{OH})_{6} \cdot 8 \mathrm{H}_{2} \mathrm{O}\end{array}$ \\
\hline Cl-pyromorphite & $\mathrm{Pb}_{5}\left(\mathrm{PO}_{4}\right)_{3} \mathrm{Cl}$ \\
\hline $\mathrm{Cu}(\mathrm{OH})_{2(\mathrm{~s})}$ & $\mathrm{Cu}(\mathrm{OH})_{2}$ \\
\hline Gibbsite & $\mathrm{Al}(\mathrm{OH})_{3}$ \\
\hline Hydroxyapatite & $\mathrm{Ca}_{5}\left(\mathrm{PO}_{4}\right)_{3}(\mathrm{OH})$ \\
\hline Leucite & $\mathrm{K}\left[\mathrm{AlSi}_{2} \mathrm{O}_{6}\right]$ \\
\hline Magadiite & $\mathrm{NaSi}_{7} \mathrm{O}_{13}(\mathrm{OH})_{3} \cdot 4\left(\mathrm{H}_{2} \mathrm{O}\right)$ \\
\hline Lime & $\mathrm{CaO}$ \\
\hline Maghemite & $\gamma-\mathrm{Fe}_{2} \mathrm{O}_{3}$ \\
\hline Magnesite & $\mathrm{MgCO}_{3}$ \\
\hline Microcline & $\mathrm{KAlSi}_{3} \mathrm{O}_{8}$ \\
\hline Octacalcium phosphate & $\mathrm{Ca}_{8} \mathrm{H}_{2}\left(\mathrm{PO}_{4}\right)_{6} \cdot 5 \mathrm{H}_{2} \mathrm{O}$ \\
\hline $\mathrm{PbMoO}_{4}$ & $\mathrm{PbMoO}_{4}$ \\
\hline Portlandite & $\mathrm{Ca}(\mathrm{OH})_{2}$ \\
\hline Quartz & $\mathrm{SiO}_{2}$ \\
\hline Willemite & $\mathrm{Zn}_{2} \mathrm{SiO}_{4}$ \\
\hline Zincite & $(\mathrm{Zn}, \mathrm{Mn}) \mathrm{O}$ \\
\hline $\mathrm{ZnO}_{(\mathrm{s})}$ & $\mathrm{ZnO}$ \\
\hline
\end{tabular}


Table S3. Chemical composition of MA-9c and FA-2b. Results are expressed in $\mathrm{mg} / \mathrm{kg}$ dw, unless differently

787 specified. The $\mathrm{pH}$ of the ashes refers to the value measured after batch leaching tests at $\mathrm{L} / \mathrm{S} 10 \mathrm{~L} / \mathrm{kg}$. [MC:

788 moisture content; TOC: total organic carbon]

\begin{tabular}{|c|c|c|c|c|c|}
\hline & MA-9c & FA-2b & & MA-9c & FA-2b \\
\hline pH (-) & 12.7 & 12.7 & Mo & $1.81(4.5 \%)$ & $3.61(14 \%)$ \\
\hline $\mathrm{MC}(\%)$ & $0.15(35 \%)$ & $47.3(4.4 \%)$ & $\mathbf{N}$ & $700(2.9 \%)$ & $1670(3.5 \%)$ \\
\hline TOC (\%) & $5.84(2.5 \%)$ & $7.39(29 \%)$ & $\mathrm{Na}$ & $10500(8.0 \%)$ & $12000(25 \%)$ \\
\hline $\mathrm{C}(\%)$ & $6.64(0.77 \%)$ & $8.28(0.80 \%)$ & Nb & $4.99(4.9 \%)$ & $2.7(9.2 \%)$ \\
\hline Ag & $0.268(2.5 \%)$ & $0.728(2.0 \%)$ & Nd & $6.22(1.6 \%)$ & $5.62(1.8 \%)$ \\
\hline Al & $12400(4.7 \%)$ & $10800(14 \%)$ & $\mathrm{Ni}$ & $16.1(2.0 \%)$ & $22.4(0.76 \%)$ \\
\hline As & $1.82(3.8 \%)$ & $2.68(8.8 \%)$ & $\mathbf{P}$ & $10000(2.6 \%)$ & $21400(1.8 \%)$ \\
\hline Au & $0.145(43 \%)$ & $0.145(9.3 \%)$ & $\mathbf{P b}$ & $13.8(4.6 \%)$ & $55.3(2.0 \%)$ \\
\hline Ba & $1170(9.9 \%)$ & $1550(0.056 \%)$ & Pd & $0.366(46 \%)$ & $<0.512$ \\
\hline Be & $1.91(58 \%)$ & $0.798(1.6 \%)$ & Pr & $1.68(1.0 \%)$ & $1.5(2.3 \%)$ \\
\hline $\mathbf{C a}$ & $135000(2.8 \%)$ & $263000(3.1 \%)$ & $\mathbf{P t}$ & $0.0115(36 \%)$ & $0.0124(73 \%)$ \\
\hline Cd & $3.99(3.4 \%)$ & $16.3(0.74 \%)$ & $\mathbf{R b}$ & $73(0.65 \%)$ & $75.4(0.79 \%)$ \\
\hline Ce & $17.5(6.2 \%)$ & $15.1(26 \%)$ & $\operatorname{Re}$ & $0.0738(35 \%)$ & $0.0999(21 \%)$ \\
\hline Co & $5.49(0.21 \%)$ & $5.79(2.0 \%)$ & $\mathbf{R h}$ & $<0.01$ & $<0.01$ \\
\hline $\mathrm{Cr}$ & $26.6(3.1 \%)$ & $60.6(3.4 \%)$ & $\mathbf{R u}$ & $0.201(110 \%)$ & $0.0122(120 \%)$ \\
\hline Cs & $1.28(23 \%)$ & $<1.05$ & $\mathbf{S}$ & $2450(5.3 \%)$ & $8490(2.8 \%)$ \\
\hline $\mathrm{Cu}$ & $60.4(2.9 \%)$ & $115(1.0 \%)$ & Sb & $1.33(3.0 \%)$ & $2.44(1.6 \%)$ \\
\hline Dy & $1.09(2.2 \%)$ & $0.934(2.0 \%)$ & Sc & $2.43(3.8 \%)$ & $1.73(5.1 \%)$ \\
\hline $\mathbf{E r}$ & $0.69(4.4 \%)$ & $0.549(2.3 \%)$ & Se & $<16.7$ & $<16.7$ \\
\hline Eu & $0.373(0.84 \%)$ & $0.315(3.6 \%)$ & $\mathbf{S i}$ & $254000(6.3 \%)$ & $124000(33 \%)$ \\
\hline $\mathbf{F e}$ & $6720(1.9 \%)$ & $6090(2.4 \%)$ & Sm & $1.19(1.3 \%)$ & $1.09(2.5 \%)$ \\
\hline Ga & $3.33(1.1 \%)$ & $2.76(8.4 \%)$ & Sn & $1.07(3.6 \%)$ & $2.51(3.3 \%)$ \\
\hline Gd & $1.25(2.5 \%)$ & $1.08(2.9 \%)$ & $\mathrm{Sr}$ & $708(3.1 \%)$ & $1240(3.6 \%)$ \\
\hline Ge & $1.54(3.9 \%)$ & $1.21(5.6 \%)$ & $\mathbf{T a}$ & $0.877(13 \%)$ & $0.438(17 \%)$ \\
\hline Hf & $3.27(8.9 \%)$ & $1.68(25.3 \%)$ & Tb & $0.195(1.6 \%)$ & $0.169(2.5 \%)$ \\
\hline Ho & $0.245(3.9 \%)$ & $0.204(1.6 \%)$ & Th & $2.25(5.0 \%)$ & $1.54(11 \%)$ \\
\hline In & $0.104(110 \%)$ & $0.0154(7.4 \%)$ & Ti & $1120(1.9 \%)$ & $616(9.8 \%)$ \\
\hline Ir & $0.134(100 \%)$ & $<0.011$ & Tl & $0.217(0.93 \%)$ & $1.98(2.8 \%)$ \\
\hline $\mathbf{K}$ & $39400(3.8 \%)$ & $51200(4.7 \%)$ & Tm & $0.114(7.0 \%)$ & $0.0854(3.6 \%)$ \\
\hline La & $7.98(1.6 \%)$ & $7.02(2.1 \%)$ & $\mathbf{V}$ & $15.9(3.4 \%)$ & $9.18(1.3 \%)$ \\
\hline $\mathbf{L i}$ & $5.7(27 \%)$ & $6.73(0.17 \%)$ & $\mathbf{W}$ & $12(44 \%)$ & $12(30 \%)$ \\
\hline Lu & $0.123(11 \%)$ & $0.0836(3.5 \%)$ & $\mathbf{Y b}$ & $0.719(6.8 \%)$ & $0.512(4.9 \%)$ \\
\hline Mg & $12700(2.3 \%)$ & $30000(3.1 \%)$ & $\mathbf{Z n}$ & $340(3.2 \%)$ & $924(0.78 \%)$ \\
\hline Mn & $7430(2.7 \%)$ & $11000(1.6 \%)$ & $\mathbf{Z r}$ & $94.2(1.2 \%)$ & $55.2(30 \%)$ \\
\hline
\end{tabular}


791 Table S4. Content of critical elements, as defined in European Commission (2014), and additional trace

792 elements in wood ash samples, grouped by ash type: bottom ash (BA), fly ash (FA) and mixed ash (MA).

793 Minimum and maximum contents are reported. Results are expressed in $\mathrm{mg} / \mathrm{kg} \mathrm{dw}$.

\begin{tabular}{|c|c|c|c|}
\hline & BA & FA & MA \\
\hline samples & BA- $1,2,3$ & FA- $1,2 a, 2 b, 3$ & $\begin{array}{c}\text { MA- } 4,5,6,7,8 \\
9 a, 9 b, 9 c, 10\end{array}$ \\
\hline \multicolumn{4}{|c|}{ OTHER TRACE AND CRITICAL ELEMENTS } \\
\hline Ag & $<0.26-0.40$ & $<0.26-1.05$ & $<0.26-2.0$ \\
\hline Au & $0.0408-0.225$ & $0.053-0.145$ & $0.0207-0.136$ \\
\hline Be & $1.61-3.89$ & $0.798-7.19$ & $0.985-6.29$ \\
\hline $\mathrm{Ce}$ & $9.96-21.5$ & $6.37-16.1$ & $10.2-14.5$ \\
\hline Cs & $<1.05-2.05$ & $<1.05-4.94$ & $<0.71-15.8$ \\
\hline Er & $0.326-0.744$ & $0.185-0.549$ & $0.402-0.558$ \\
\hline $\mathbf{E u}$ & $0.188-0.313$ & $0.083-0.315$ & $0.179-0.271$ \\
\hline Ga & $4.03-4.57$ & $<2.76-4.58$ & $<2.62-5.27$ \\
\hline Gd & $0.697-1.6$ & $0.462-1.34$ & $0.711-1.22$ \\
\hline Ge & $0.871-0.947$ & $0.528-1.21$ & $0.641-1.32$ \\
\hline Hf & $0.851-2.04$ & $0.359-1.68$ & $0.904-2.1$ \\
\hline Ho & $0.0783-0.238$ & $0.0278-0.204$ & $0.111-0.192$ \\
\hline In & $<0.005-0.2$ & $<0.0101-0.2$ & $<0.005-0.2$ \\
\hline Ir & $0.0169-0.291$ & $<0.011-0.517$ & $0.0115-0.976$ \\
\hline $\mathbf{L a}$ & $5.67-11.2$ & $3.67-8.49$ & $5.86-8.21$ \\
\hline $\mathbf{L i}$ & $5.0-9.87$ & $5.12-16.5$ & $3.67-8.35$ \\
\hline Lu & $0.0209-0.114$ & $<0.009-0.0836$ & $0.0298-0.0882$ \\
\hline $\mathbf{N b}$ & $2.36-5.83$ & $1.2-5.58$ & $3.03-5.21$ \\
\hline Nd & $3.64-8.84$ & $2.33-6.62$ & $3.9-5.94$ \\
\hline Pd & $<0.22-0.512$ & $<0.512-1.45$ & $<0.22-0.512$ \\
\hline Pr & $1.13-2.54$ & $0.698-1.86$ & $1.21-1.7$ \\
\hline $\mathbf{P t}$ & $0.0091-0.0143$ & $0.0124-0.0327$ & $<0.0115-0.0323$ \\
\hline $\mathbf{R b}$ & $83.9-148$ & $75.4-143$ & $64.7-396$ \\
\hline $\mathbf{R e}$ & $0.058-0.135$ & $0.0615-0.13$ & $<0.04-0.117$ \\
\hline $\mathbf{R h}$ & $<0.01$ & $<0.01$ & $<0.01$ \\
\hline Ru & $<0.002-0.4$ & $<0.002-0.4$ & $<0.002-0.4$ \\
\hline Sc & $1.95-2.32$ & $<1.11-1.77$ & $1.59-2.47$ \\
\hline Sm & $0.737-1.49$ & $0.437-1.24$ & $0.761-1.15$ \\
\hline $\mathbf{T a}$ & $0.175-0.307$ & $0.0423-0.438$ & $0.126-0.381$ \\
\hline $\mathbf{T b}$ & $0.0975-0.195$ & $0.0522-0.169$ & $0.112-0.149$ \\
\hline $\mathbf{T i}$ & $696-1750$ & $371-4530$ & $747-1580$ \\
\hline $\mathbf{T m}$ & $0.0224-0.117$ & $<0.022-0.102$ & $<0.022-0.101$ \\
\hline $\mathbf{W}$ & $0.537-1.49$ & $0.905-12$ & $0.504-1.53$ \\
\hline $\mathbf{Y b}$ & $0.329-0.653$ & $0.14-0.512$ & $0.359-0.594$ \\
\hline $\mathrm{Zr}$ & $32.9-78.6$ & $13.6-55.2$ & $35.3-86$ \\
\hline
\end{tabular}


796 Table S5. Compliance leaching test results, grouped by ash type (BA, FA and MA): "other trace and critical

797 elements". Results are expressed in $\mathrm{mg} / \mathrm{kg}$ dw. Minimum and maximum contents are reported. Leaching tests

798 were carried out at the L/S ratio $2 \mathrm{~L} / \mathrm{kg}$ (EN 12457-1:2002) and $10 \mathrm{~L} / \mathrm{kg}$ (EN 12457-3:2002).

\begin{tabular}{|c|c|c|c|c|c|}
\hline & BA (L/S 2) & FA (L/S 2) & MA (L/S 2) & MA (L/S 10) & FA (L/S 10) \\
\hline samples & BA- $1,2,3$ & FA- $2 a, 2 b$ & $\begin{array}{c}\text { MA- } 4,5,6,7,8 \\
9 \mathrm{a}, 9 \mathrm{~b}, 9 \mathrm{c}, 10\end{array}$ & MA-9c & FA-2b \\
\hline \multicolumn{6}{|c|}{ OTHER TRACE AND CRITICAL ELEMENTS } \\
\hline Ag & $<0.0026-0$ & $<0.0026-0.0036$ & $<0.0026$ & $<0.013$ & $<0.013$ \\
\hline Au & $<0.00018-0.0016$ & $<0.00019$ & $<0.00018-0.0028$ & $<0.0009$ & $<0.0009$ \\
\hline Be & $0.0055-0.0063$ & $<0.0022-0.012$ & $<0.0023-0.017$ & 0.039 & 0.043 \\
\hline $\mathrm{Ce}$ & $<0.00051$ & $<0.00053$ & $<0.00069$ & $<0.0025$ & $<0.0025$ \\
\hline Cs & $0.043-0.14$ & $0.38-0.45$ & $0.055-1.3$ & 0.13 & 0.36 \\
\hline $\mathbf{E r}$ & $<0.00036$ & $<0.00037$ & $<0.00049$ & 0.0019 & $<0.0018$ \\
\hline Eu & $0.00015-0.0002$ & $<0.00014$ & $<0.00013-0.00045$ & $<0.00066$ & $<0.00066$ \\
\hline Ga & $<0.0088-0.031$ & $<0.0092$ & $<0.0088-0.21$ & $<0.044$ & $<0.044$ \\
\hline Gd & $0.00022-0.00033$ & $<0.00012-0.00027$ & $0.00016-0.021$ & 0.0019 & 0.00098 \\
\hline Ge & $<0.00085-0.0026$ & $<0.00088-0.012$ & $<0.00091-0.0065$ & 0.011 & 0.014 \\
\hline Hf & $<0.00025-0$ & $<0.00026$ & $<0.00025$ & $<0.0013$ & $<0.0013$ \\
\hline Ho & $<0.00018-0.00023$ & $<0.00019$ & $<0.0002-0.00038$ & 0.0012 & $<0.00092$ \\
\hline In & $<0.000046$ & $0.000049-0.00095$ & $<0.000046-0.00068$ & $<0.00023$ & $<0.00023$ \\
\hline Ir & $<0.00011-0.00051$ & $<0.00011-0.0064$ & $<0.00011-0.059$ & $<0.00056$ & $<0.00056$ \\
\hline La & $<0.0011$ & $<0.0012$ & $<0.0015$ & $<0.0055$ & $<0.0055$ \\
\hline $\mathbf{L i}$ & $0.03-0.26$ & $0.053-0.23$ & $0.013-0.14$ & 0.17 & 0.63 \\
\hline Lu & $<0.00026-0.00026$ & $<0.00027$ & $<0.00035-0.00039$ & $<0.0013$ & $<0.0013$ \\
\hline $\mathbf{N b}$ & $<0.00022$ & $<0.00023$ & $<0.00022$ & $<0.0011$ & $<0.0011$ \\
\hline Nd & $<0.00049-0.00053$ & $<0.00051-0.00053$ & $<0.00067$ & $<0.0025$ & $<0.0025$ \\
\hline Pd & $<0.0051$ & $<0.0053$ & $<0.007$ & $<0.026$ & $<0.026$ \\
\hline Pr & $<0.00035-0.00039$ & $<0.00036-0.00045$ & $<0.00048-0.006$ & 0.002 & 0.0019 \\
\hline $\mathbf{P t}$ & $<0.000065-0.00018$ & $<0.000067-0.000065$ & $<0.000065-0.00021$ & $<0.00032$ & 0.0004 \\
\hline $\mathbf{R b}$ & $6.4-38$ & $53-88$ & $11-140$ & 22 & 57 \\
\hline $\operatorname{Re}$ & $0.00011-0.00057$ & $0.00015-0.00073$ & $0.00018-0.0017$ & $<0.00041$ & 0.00097 \\
\hline $\mathbf{R h}$ & $<0.000099-0$ & $<0.0001$ & $<0.000099$ & $<0.0005$ & $<0.0005$ \\
\hline $\mathbf{R u}$ & $0.00013-0.00023$ & $0.00086-0.0009$ & $<0.000024-0.003$ & 0.0012 & 0.0017 \\
\hline Sc & $<0.0044$ & $<0.0045$ & $<0.006-0.04$ & $<0.022$ & $<0.022$ \\
\hline Sm & $<0.00019-0.00037$ & $<0.00019-0.00054$ & $<0.0002-0.00085$ & 0.0017 & 0.0019 \\
\hline Ta & $<0.00057$ & $<0.00059$ & $<0.00077$ & $<0.0028$ & $<0.0028$ \\
\hline Tb & $<0.000048$ & $<0.00005$ & $<0.000048$ & $<0.00024$ & $<0.00024$ \\
\hline Ti & $<0.012-0.053$ & $<0.013$ & $<0.012-0.046$ & $<0.06$ & $<0.06$ \\
\hline Tm & $<0.00024-0.00028$ & $<0.00025$ & $<0.00024-0.00031$ & 0.0013 & $<0.0012$ \\
\hline $\mathbf{W}$ & $0.045-0.21$ & $0.0081-0.2$ & $0.006-0.52$ & 0.036 & 0.16 \\
\hline Yb & $<0.00035-0.00038$ & $<0.00036-0.00037$ & $<0.00035-0.00038$ & 0.0019 & $<0.0017$ \\
\hline $\mathbf{Z r}$ & $<0.0000094$ & $<0.0000098$ & $<0.0000094-0.000051$ & $<0.000047$ & $<0.000047$ \\
\hline
\end{tabular}




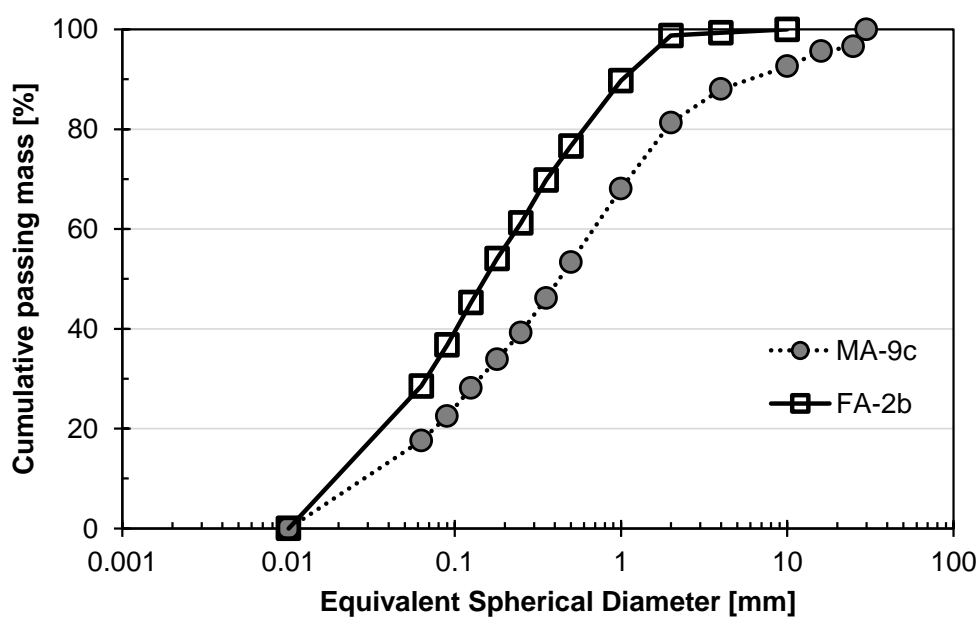

801

802 Figure S1. Particle size distribution curves for MA-9c and FA-2b.

803

804

805

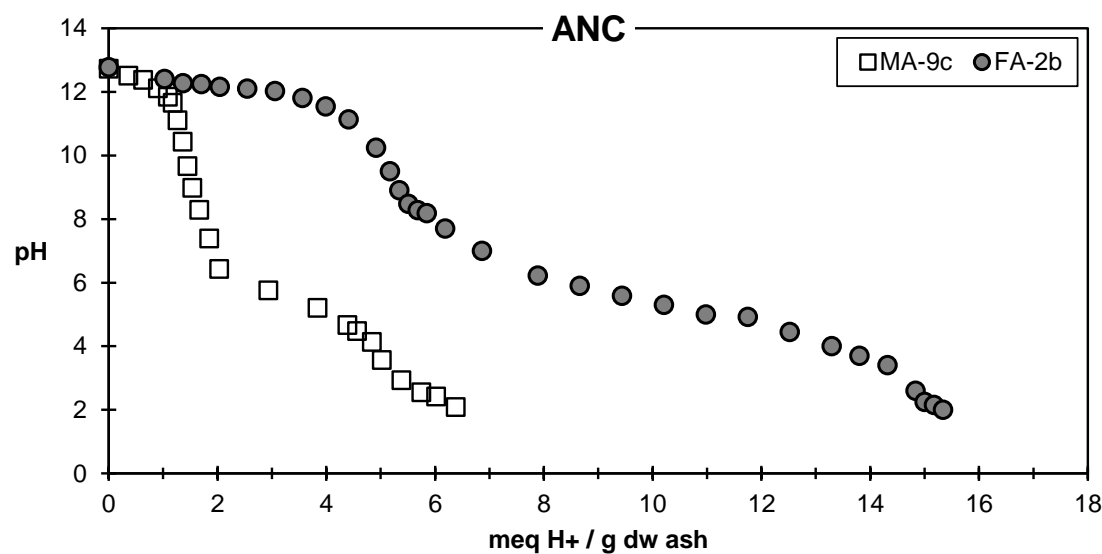

806

807 Figure S2. Acid neutralisation capacity (ANC) curves for FA-2b and MA-9c. 

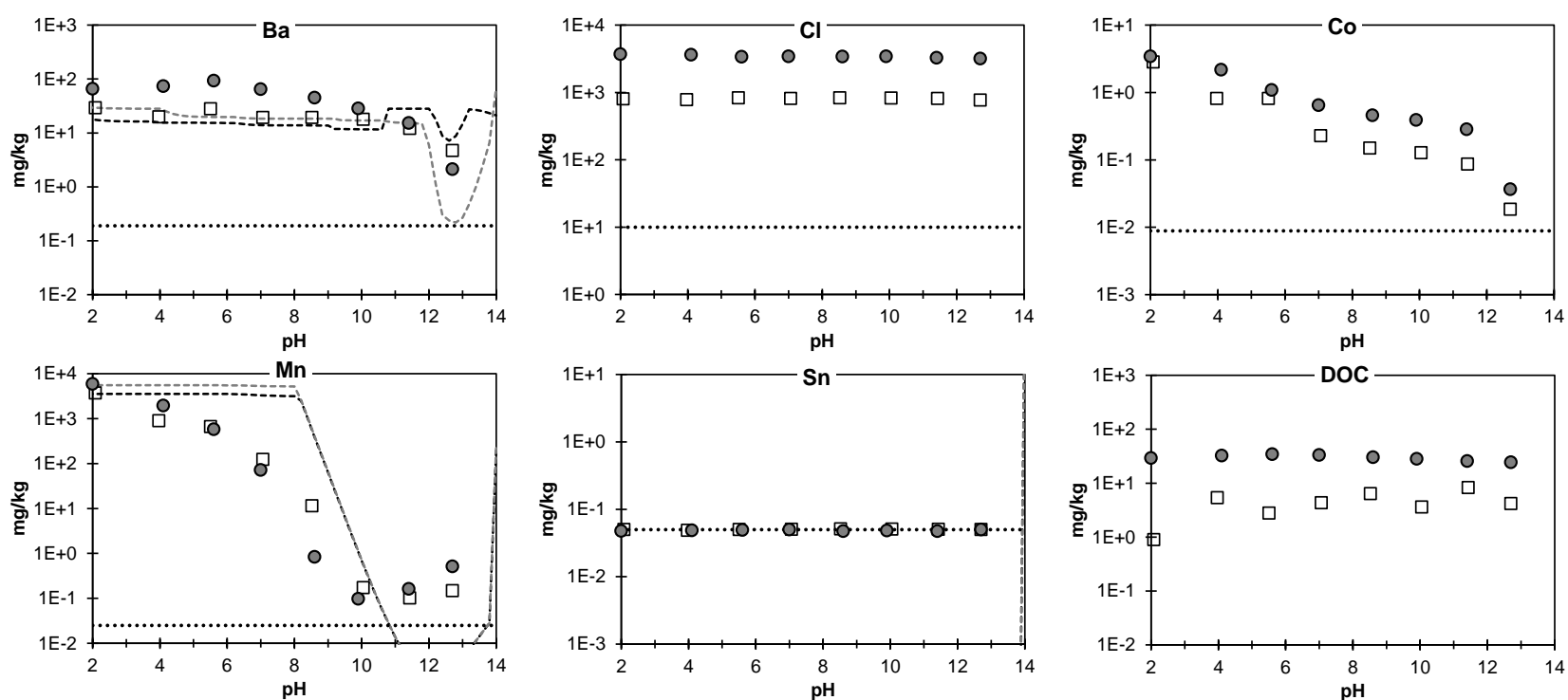

810 Figure S3. $\mathrm{pH}-$ dependent leaching test results in comparison with geochemical model predictions: $\mathrm{Ba}, \mathrm{Cl}, \mathrm{Co}$,

$811 \mathrm{Mn}, \mathrm{Sn}, \mathrm{Tl}$ and DOC. The results are expressed as leached amount (in $\mathrm{mg} / \mathrm{kg} \mathrm{dw}$ ). Dots and squares series

812 represent measured values for FA-2b and MA-9c, respectively. Dashed lines represent Model II (m II)

813 predictions. [LOD: limit of detection]

815 Section S1. Acid neutralisation capacity (ANC):

816 ANC was determined according to CEN/TS 14997:2006 (E) using $60 \mathrm{~g}$ of ash wet weight and adding distilled

817 water until the $\mathrm{L} / \mathrm{S}$ ratio $9 \mathrm{~L} / \mathrm{kg}$. The mixture was mixed for about an hour, and let it settled for 10 minutes before

818 measuring the solution $\mathrm{pH}$. Next, small amounts of $\mathrm{HNO}_{3}$ were added, the mixture was mixed for 20 minutes, let

819 it settled for 5 minutes and the solution $\mathrm{pH}$ was measured; new acid was added and the procedure was repeated until a $\mathrm{pH}$ of 2 was measured.

821 